Enclosure, Grainger to Vogt, ANNUAL REVIEW OF CULTURAL RESOURCES INVESTIGATIONS, SAVANNAH RIVER ARCHAEOLOGICAL RESEARGH RROGRAM (SRAP) - FY 1993, dated $\mathrm{DEF}$ \& 7

$\mathrm{DOE} / \mathrm{SR} / 15199-6$

\title{
ANNUAL REVIEW OF CULTURAL RESOURCE INVESTIGATIONS BY THE SAVANNAH RIVER ARCHAEOLOGICAL RESEARCH PROGRAM
}

FISCAL YEAR 1993

This report was prepared as an account of work sponsored by an agency of the United States Government. Neither the United States Government nor any agency thereof, nor any of their employees, makes any warranty, express or implied, or assumes any legal liability ot responsibility for the accuracy, completeness, or usefulness of any information, apparatus, product, or process disclosed, or represents that its use would not infringe privately owned rights. Reference herein to any specific commercial product, process, or service by trade name, trademark, manufacturer, or otherwise does not necessarily constitute or imply its endorsement, recommendation, or favoring by the United States Government or any agency thereof. The views and opinions of authors expressed herein do not necessarily state or reflect those of the United States Government or any agency thereof.

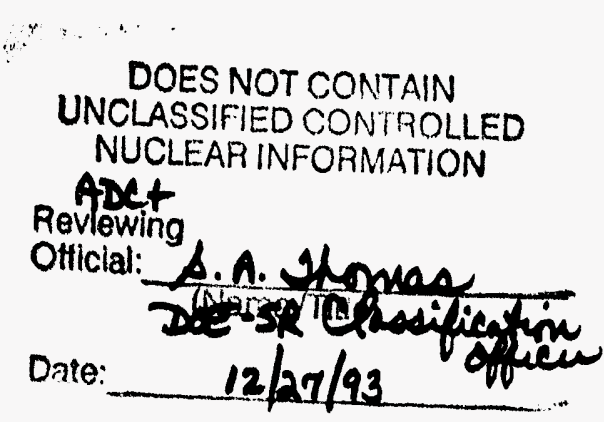

SAVANNAH RIVER ARCHAEOLOGICAL RESEARCH PROGRAM SOUTH CAROLINA INSTITUTE OF ARCHAEOLOGY AND ANTHROPOLOGY UNIVERSITY OF SOUTH CAROLINA

October 1993

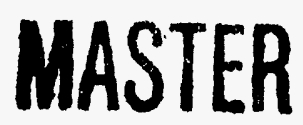


"This report was prepared as an account of work sponsored by an agency of the United States Government. Neither the United States Government nor any agency thereof, nor any of their employees, makes any warranty, express or implied, or assumes any legal liability or responsibility for the accuracy, completeness, or usefulness of any information, apparatus, product, or process disclosed, or represents that its use would not infringe privately owned rights. Reference herein to any specific commercial product, process, or service by trade name, trademark, manufacturer, or otherwise, does not necessarily constitute or imply its endorsement, recommendation, or favoring by the United States Government or any agency thereof. The views and opinions of authors expressed herein do not necessarily state or reflect those of the United States Government or any agency thereof."

\title{
ANNUAL REVIEW OF CULTURAL RESOURCE INVESTIGATIONS BY THE SAVANNAH RIVER ARCHAEOLOGICAL RESEARCH PROGRAM
}

FISCAL YEAR 1993

\author{
Prepared by \\ the staff of the \\ SAVANNAH RIVER \\ ARCHAEOLOGICAL RESEARCH PROGRAM
}

This report was prepared through funding provided by the United States Department of Energy under contract DE-FC09-88SR15199.

The report was prepared as an account of work sponsored by the United States Government. Neither the United States nor the United States Department of Energy, nor their employees, nor any of their contractors, subcontractors, or their employees, make any warranty for the accuracy, completeness, or usefulness of any information, apparatus, product or process disclosed, or represent that its use would not infringe privately-owned rights.

\section{SAVANNAH RIVER ARCHAEOLOGICAL RESEARCH PROGRAM SOUTH CAROLINA INSTITUTE OF ARCHAEOLOGY AND ANTHROPOLOGY UNIVERSITY OF SOUTH CAROLINA}

October 1993 


\section{SAVANNAH RIVER ARCHAEOLOGICAL RESEARCH PROGRAM}

\section{Eull-time Staff}

Mark J. Brooks

Richard D. Brooks

Kenneth E. Sassaman

David C. Crass

D. Keith Stephenson

Mary M. Inkrot

J. Christopher Gillam

Melanie Cabak

Bruce R. Penner

Tammy R. Forehand

Charles J. Rinehart

Kristina M. Monaco

George L. Wingard

Tonya A. Browder

George S. Lewis
Co-Program Manager/Geoarchaeologist

Co-Program Manager/Historian

Special Projects Archaeologist

Curator/Historic Sites Archaeologist

Site-Use Archaeologist

Heritage Education Specialist

Survey Archaeologist

Survey Archaeologist

Curatorial Assistant

Curatorial Assistant

NPR Archaeologist

Field/Laboratory Assistant

Field/Laboratory Assistant

Community Historian

Administrative/Archaeological Assistant

Graduate Research Assistants, University of South Carolina. Columbia

Hugh Bowers

Ph.D. Program, Department of History

Sarah Jo Evans

M.A. Program, Department of Anthropology

Undergraduate Assistants. University of South Carolina-Aiken

Robert M. Anderson

Laboratory Assistant

Lea Simons

Laboratory Assistant

Stephen W. McKettrick

Field/Laboratory Assistant

John Huffman

Laboratory Assistant

National Science Foundation Internship. University of South Carolina-Aiken

Preston Dyches

Archival Research

Qak Ridge Associated Universities. Undergraduate Student Research Participant

Sherry A. Leis

Beloit College, Wisconsin 


\section{MANAGEMENT SUMMARY}

The Savannah River Archaeological Research Program (SRARP) continued through FY93 with the United States Department of Energy to fulfill a threefold mission of cultural resource management, research, and public education at the Savannah River Site.

Some 1,937 acres of land on the SRS came under cultural resources review in FY93. This activity entailed 22 field surveys, resulting in the recording of 66 new sites. Eighteen existing sites within survey tract boundaries were revisited to update site file records.

Research conducted by SRARP was reported in four journal articles/book chapters and nine monographs/reports published during FY93. SRARP staff also presented research results in 14 papers at professional meetings, and organized one symposium.

In the area of public education, the SRARP intensified its activities in FY93 with the additional of a full-time Heritage Education Specialist and expansion of the Community History Project. Volunteer excavations at the Tinker Creek site were continued with the Augusta Archaeological Society and other avocational groups, and other off-site excavations provided a variety of opportunities for field experience. Over 50 presentations, displays and tours were provided for schools, historical societies, civic groups, and environmental and historical awareness day celebrations. Additionally, SRARP staff taught three anthropology courses at area colleges and universities. 


\section{TABLE OF CONTENTS}

INTRODUCTION

PART I. CULTURAL RESOURCE MANAGEMENT 6

RESULTS OF FY93 SITE USE, TIMBER COMPARTMENT

AND CLEARCUT SURVEYS (D. K. Stephenson) .............................................6

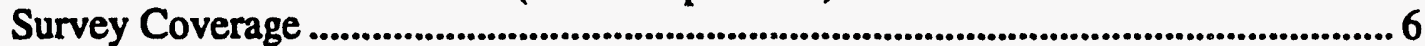

Descriptions of SR-88 Site Use Archaeological Surveys, FY93 ...............................9

Survey Results................................................................................................................... 12

CURATION COMPLIANCE ACTIVITIES (D. C. Crass) .............................................. 15

38CFR Compliance Activities ......................................................................................... 15

NAGPRA Compliance Activities ................................................................................. 17

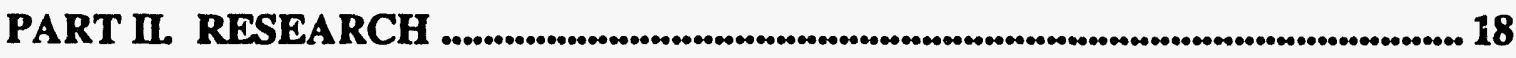

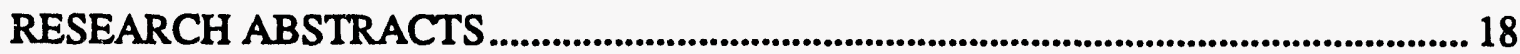

RESEARCH NOTES ................................................................................................. 22

The Savannah River Backcountry (D.C. Crass) ............................................................. 22

Graduate Research in Primary Documents (D. C. Crass) ........................................... 23

National Science Foundation Young Scholars Program (D. C. Crass) ...................... 23

Woodrow Wilson Boyhood Home (D. C. Crass)........................................................... 23

Midden Point Project (K. E. Sassaman) ...................................................................... 24

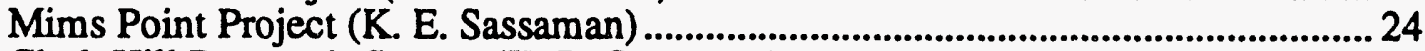

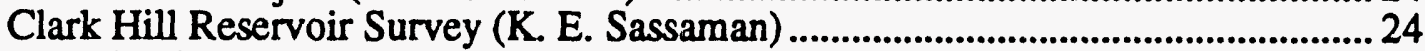

Investigations at a Middle Mississippian Site on the Georgia Coastal Plain

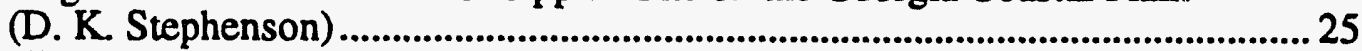

Middle Woodland Research in South Georgia (D. K. Stephenson) ............................. 25

RESEARCH FELLOWSHIPS AND GRANTS (R. D. Brooks) ................................... 26

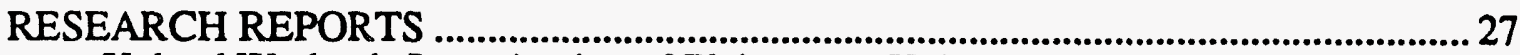

Upland Wetlands Investigation of Pleistocene-Holocene

Environmental Change on the SRS: 1993

(M. J. Brooks, B. E. Taylor, J. A. Grant, and E. Gaiser) ................................... 27

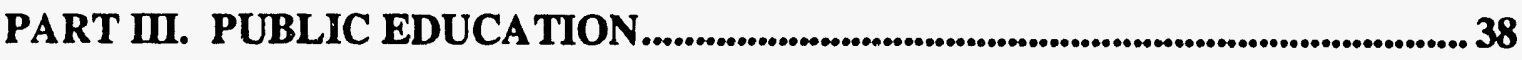

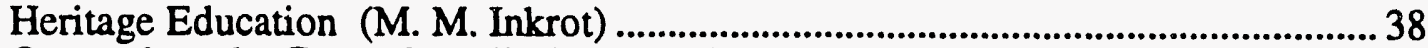

Outreach to the General Public (M. M. Inkrot) ........................................................ 38

Community History Project (T. A. Browder) ................................................................. 39

Volunteer Excavation Projects (M. M. Inkrot and K. E. Sassaman) .......................... 40

Additional Involvement with Avocational Groups (G. S. Lewis) .................................. 41

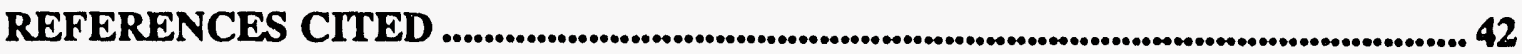

APPENDIX A: Publications and Activities ......................................................... 45 


\section{INTRODUCTION}

A cooperative agreement with the United States Department of Energy provides the necessary funding for the Savannah River Archaeological Research Program (SRARP) of the South Carolina Institute of Archaeology and Anthropology, University of South Carolina, to render services required under federal law for the protection and management of archaeological resources on the Savannah River Site (SRS). Because the significance of archaeological resources is usually determined by research potential, the SRARP is guided by research objectives. An ongoing research program provides the theoretical, methodological, and empirical basis for assessing site significance within the compliance process specified by law. In accordance with the spirit of the law, the SRARP maintains an active public education program for disseminating knowledge about prehistory and history, and for enhancing awareness of historic preservation. This report summarizes the management, research, and public education activities of the SRARP during Fiscal Year 1993.

SRARP management procedures were modified in FY90 for the implementation in FY91 of a Programmatic Memorandum of Agreement (PMOA) among the United States Department of Energy-Savannah River Operations Office, the South Carolina State Historic Preservation Office and the Advisory Council on Historie-Preservation. The SRARP is now required under the PMOA to produce an annual review of all cultural resource activities conducted during the year. The reader is referred to the SRARP FY90 Annual Review for a detailed discussion of the new procedures and databases.

The following section (Part I) on Cultural Resource Management contains the results of the FY93 surveys and an update on curation activities. Research activities of the SRARP are summarized in Part II and include prehistoric, historic, and geoarchaeologic studies conducted on the SRS and in the surrounding region. An extralocal perspective is necessary for understanding the effects of regional processes on local conditions and, hence, enables the more effective management of the cultural resources of the SRS.

Public education activities of the SRARP are summarized in Part III, which highlights the expanded heritage education program, volunteer excavations, involvement with avocational archaeology groups, and the community history project. An appendix at the end of the report lists the FY93 professional and public service activities of the SRARP staff. 
Savannah River Archaeological Research Program

\title{
PART I. CULTURAL RESOURCE MANAGEMENT
}

\author{
RESULTS OF FY93 SITE USE, TIMBER COMPARTMENT, \\ AND CLEARCUT SURVEYS
}

\section{Survey Coverage}

Archaeological survey of Site Use Application and Timber Compartment Prescription land tracts by SRARP staff continued through the FY93 period according to procedures outlined and implemented in 1990 (SRARP 1990:7-17). In addition, clearcut surveys initiated in January of 1990 have continued this year as an important means of improving survey recovery from timber compartments. Finally, the opportunity to record sites on a non-compliance related basis presented itself from time to time. Altogether, 22 survey and testing projects were conducted in FY93. During this period, 41 tracts of land comprising 1,937 acres were surveyed, resulting in the location of 66 new sites and revisits to 18 previously recorded sites. This section summarizes all Site Use, Timber Compartment, and Clearcut Survey coverage and results.

Site Use Applications. A total of 95 Site Use Applications were received by the SRARP during FY93. SRARP staff screened each of these applications for proposed land alteration, and found that only seven required detailed review of existing archaeological documentation. Six of these projects were fully completed in FY93 and comprise 32 percent or 628 acres of the total land surveyed in FY93. The seventh project, the E Area survey, commenced in the summer of 1993, but continues at the time of this writing and will not be completed until late 1993. Survey of the $1,000+$ acre E Area project area will be fully reported in a separate document in FY94.

The Site Use surveys conducted in FY93 included some large-scale projects such as the Savannah River Ecology Laboratory Conference Center and Educational Facility, the Central Sanitary Wastewater Treatment Facility, and the F/H Area Surface Enhancement Project. Following the completion of each project, full reports were prepared and submitted to the Savannah River Operations Office, U. S. Department of Energy (Sassaman and Gillam 1993; Stephenson and Sassaman 1993; Stephenson et al. 1993). The remaining Site Use Applications involved land use activities on a more limited scale. These projects included accessing soils for the repair of the Par Pond dam, the construction of an effluent pipeline associated with Central Shops, and the restoration of a Carolina Bay to its natural state. Table 1 summarizes each Site Use Application, the project area size, and new or existing sites located within the project areas. Descriptions of these projects, survey methods, and results are presented below.

Timber Compartment Prescriptions. Most of the land-altering activities receiving archaeological review in FY93 involved timber compartment stands slated for thinning or clearcutting. Due to revised regulations regarding endangered species habitat management along with tornado damage on the Savannah River Site (SRS), many timber stands were reconfigured by the United States Forest Service during the last two years. This process, along with an overall reduction in logging, offset the pre-planned schedule of timber clearcuts and thinnings on the SRS. The log jam created by this process was released in late FY93 as the SRARP received twelve prescriptions maps in a two month period. Little of this area could be surveyed in FY93, but all of the prescription maps were reviewed for existing sites and archaeological potential. Survey of these stands will continue during FY94.

Of the 9,183 acres implicated in the twelve compartment prescriptions received in FY93, only 607 acres were surveyed. The majority of this area (416 acres) involved 
Table 1. FY93 SR-88 Site Use Projects.

\begin{tabular}{|c|c|c|c|c|}
\hline Project & $\begin{array}{c}\text { Size } \\
\text { (acres) }\end{array}$ & $\begin{array}{c}\text { Distance } \\
\text { (em) }\end{array}$ & Sites Revisits & New Sites \\
\hline $\begin{array}{l}\text { Savannah River Ecology Laboratory } \\
\text { Conference Center and Educational Facility } \\
\text { associated right-of-way }\end{array}$ & 70 & 1.8 & $\begin{array}{l}\text { 38AK288 } \\
\text { 38AK287 } \\
\text { 38AK289 }\end{array}$ & 38AK466 \\
\hline F/H Area Surface Enhancement Project & 480 & & $\begin{array}{l}\text { 38AK146 } \\
\text { 38BR57 }\end{array}$ & $\begin{array}{l}\text { 38AK534 } \\
\text { 38AK535 } \\
\text { 38AK536 } \\
\text { 38AK537 } \\
\text { 38AK538 } \\
\text { 38AK539 } \\
\text { 38AK540 } \\
\text { 38AK541 } \\
\text { 38AK543 } \\
\text { 38AK544 }\end{array}$ \\
\hline $\begin{array}{c}\text { Central Sanitary Wastewater Treatment Facility } \\
\text { associated trunkline routes }\end{array}$ & 6 & 29.0 & $\begin{array}{l}\text { 38AK92 } \\
38 A K 145 \\
38 A K 415 \\
38 A K 417 \\
38 A K 419 \\
38 A K 436\end{array}$ & $38 \mathrm{AK} 465$ \\
\hline Carolina Bay Restoration Project & 8 & & $\begin{array}{l}\text { 38BR711 } \\
\text { 38BR715 } \\
\text { 38BR716 }\end{array}$ & \\
\hline Borrow Pit for Par Pond Dam Repair & 64 & & & \\
\hline Central Shops Sanitary Effluent Route & & 0.1 & & \\
\hline
\end{tabular}

stands slated for thinning, a land-use activity with minimal site impact. Twenty-seven sites were located in this area (Table 2). Stands slated for clearcutting (191 acres) yielded an additional three sites. Survey techniques in both thinning and clearcut stands involved subsurface testing, as well as surface reconnaissance. Although subsurface techniques are routinely used in clearcut stands because of the greater potential for subsurface damage, the employment of shovel tests in thinning stands greatly increased the number of sites found per unit surveyed in FY93.

Clearcut Survey. Additional archaeological coverage in timber compartments consisted of pedestrian survey in timber compartment stands that had recently been clearcut (usually within the last five years). As inventoried in Table 3,15 stands, totalling 702 acres, in nine timber compartments were subjected to surface reconnaissance this year. This effort resulted in the discovery of 27 new sites. It is noteworthy that, due to new policies instituted by the Savannah River Forest Station regarding terrain alteration, clearcuts are not being prepared as intensively as in the past. Rather than mechanically shearing and raking all surface debris into windrows prior to replanting, the Forest Serrice is more often preparing clearcuts with controlled burns, herbicides, or just allowing the debris to decompose in place. Although these preparation methods are less damaging to subsurface archaeological resources and the environment in 
Table 2. Tabulation of Timber Compartment Prescriptions and Results, FY93.

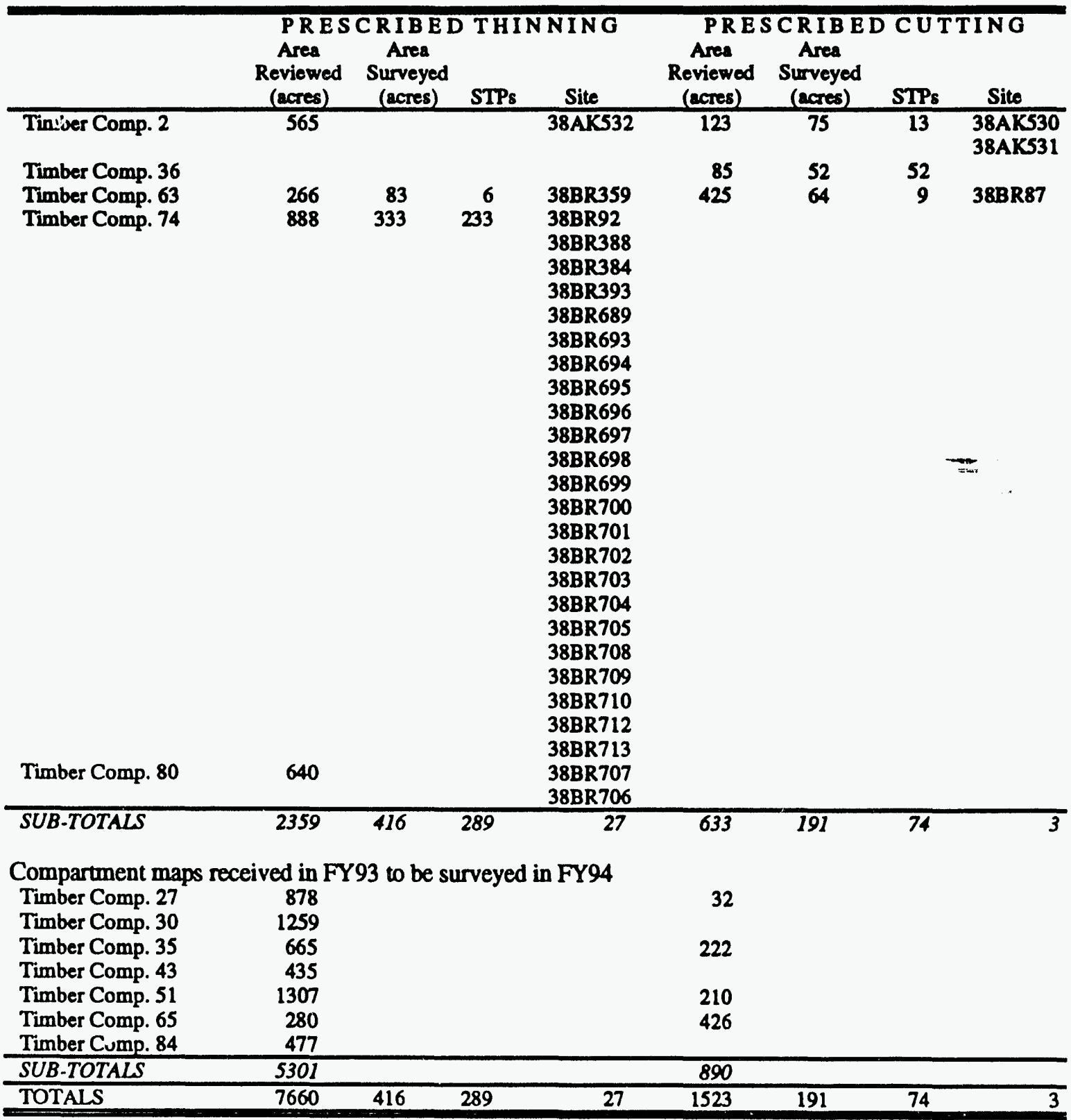

general (less erosion and decaying debris replenishes soil nutrients), they do preclude optimum archaeological survey. In fact, it has become increasingly more difficult to find clearcuts on the SRS with enough surface exposure to conduct reliable surface surveys.

Opportunistic Site Investigations. Categorized as "Opportunistic," one site (38AK533) was discovered by SRARP staff on a tract of land adjacent to a Site Use survey tract. This site was recorded but not tested. 
Table 3. Tabulation of New Sites by Clearcut Survey, FY93.

\begin{tabular}{|c|c|c|}
\hline & Size (acres) & New Sites \\
\hline $\begin{array}{l}\text { Timber Compartment } 1 \\
\text { Stand } 21\end{array}$ & 34 & $\begin{array}{l}38 A K 527 \\
38 A K 528 \\
38 A K 529\end{array}$ \\
\hline $\begin{array}{l}\text { Timber Compartment } 6 \\
\text { Stand } 1\end{array}$ & 37 & 38AKS13 \\
\hline $\begin{array}{l}\text { Timber Compartment } 8 \\
\text { Stand } 10 \\
\text { Timber Compartment } 15\end{array}$ & 47 & No sites \\
\hline $\begin{array}{l}\text { Stand } 33 \\
\text { Timber Compartment } 17\end{array}$ & 68 & 38AK526 \\
\hline $\begin{array}{l}\text { Stand } 1 \\
\text { Timber Compartment } 22\end{array}$ & 36 & 38AKS42 \\
\hline $\begin{array}{l}\text { Stand } 26 \\
\text { Timber Compartment } 23\end{array}$ & 16 & 38AKS21 \\
\hline Stand 9 & 14 & $\begin{array}{l}38 A K 514 \\
38 A K 515 \\
38 A K 516 \\
38 A K 517 \\
38 A K 518 \\
38 A K 519 \\
38 A K 520\end{array}$ \\
\hline Stand 18 & 53 & $\begin{array}{l}38 A K 467 \\
38 A K 524 \\
38 A K 525\end{array}$ \\
\hline $\begin{array}{l}\text { Stand } 25 \\
\text { Stand } 38\end{array}$ & $\begin{array}{l}22 \\
62\end{array}$ & $\begin{array}{l}\text { 38AK468 } \\
\text { 38AK522 } \\
\text { 38AK523 }\end{array}$ \\
\hline $\begin{array}{l}\text { Timber Compartment } 73 \\
\text { Stand } 3\end{array}$ & 44 & $\begin{array}{l}\text { 38BR690 } \\
\text { 38BR691 } \\
\text { 38BR692 }\end{array}$ \\
\hline $\begin{array}{l}\text { Timber Compartment } 75 \\
\text { Stand } 20 \\
\text { Stand } 21 \\
\text { Stand } 23\end{array}$ & $\begin{array}{l}34 \\
98 \\
71\end{array}$ & $\begin{array}{l}\text { 38BR688 } \\
\text { 38BR686 } \\
\text { 38BR685 } \\
\text { 38BR687 }\end{array}$ \\
\hline$\frac{\text { Stand } 24}{\text { TOTAL }}$ & $\frac{66}{702}$ & $\frac{\text { No sites }}{27 \text { sites }}$ \\
\hline
\end{tabular}

\section{Descriptions of SR-88 Site Use Archaeological Surveys, FY93}

The following project descriptions review the various survey methods used, circumstances that dictated these methods, and the results. Certain aspects of archaeological work were standardized for all projects and these are outlined here to avoid unnecessary repetition. Prior to all field work, a review of mid-twentieth century aerial photographs was conducted to identify standing historic structures that existed within project areas. The SRARP site files were consulted to identify cultural resources previously recorded in project areas. Often, survey methods included the excavation of shovel test pits (STPs) to discover subsurface archaeological deposits. All shovel tests were $35 \times 35 \mathrm{~cm}$ square, and were excavated to a depth of at least $80 \mathrm{~cm}$ unless clay substratum was encountered first. The soil from shovel tests was passed through a 0.25 inch wire mesh and artifacts were collected and bagged by provenience. 
Savannah River Archaeological Research Program

Savannah River Ecology Laboratory (SREL) Conference Center and Educational Facility (SU 91-89-C). The following description of archaeological investigations for the proposed SREL Conference Center is summarized from the report recently prepared by Stephenson et al. (1993). The Site Use requested the acquisition of a 70-acre parcel by the Savannah River Ecology Laboratory for the construction and use of a conference building and educational facility. Although this is a relatively large tract, the majority of the project area will remain preserved in its present natural state. In line with the educational facility concept, development and maintenance of nature trails, gardens and research demonstration areas are planned. Only a small portion of the actual project area (5-10 acres) will be impacted by construction and research activity.

Archaeological survey at the proposed location of the SREL Conference Center commenced on August 19, 1992 and continued intermittently through January 15, 1993 for a total of 43 work days. The proposed footprint for the SREL Conference Center and associated utility right-of-way was changed slightly over the course of archaeological investigations for the project. Field work included 400 shovel tests and the excavation of five $1 \times 1 \mathrm{~m}$, eight $1 \times 2 \mathrm{~m}$, and one $2 \times 2 \mathrm{~m}$ test units. Six previously recorded sites, one new site and two artifacts occurrences were investigated during the project. Survey entailed intensive subsurface testing to delineate the boundaries of two previously recorded sites, 38AK289 and 38AK287, located within the project area. Both sites contain stratified archaeological deposits that span 10,000 years of prehistory and history ano therefore have the potential to yield significant data on human occupations of the Aiken Plateau. As such, these sites were considered eligible for nomination to the National Register of Historic Places (NRHP). The SRARP, however, recommended that adverse effects to these sites from proposed construction be mitigated through avoidance. In consultation with the SREL personnel, construction within the site boundaries of 38 AK289 was redesigned to avoid impacts to significant components of the site. In short, the relocated building footprint will altogether avoid components situated within the upper $70 \mathrm{~cm}$ of site deposits. Ephemeral Early Archaic (ca. 9500-8000 B.P.) deposits within 38AK289 are located in the building footprint at a depth range of $70-100 \mathrm{~cm}$ below surface. Because these consist of low-density artifact assemblages that are duplicated by similar assemblages in portions of the project area that will be undisturbed, the proposed construction will have no effect on 38AK289. Site 38AK287 is located in the proposed utility right-of-way and can be completely avoided by spanning the site with an aerial transmission line.

A third site, 38AK466, was discovered through survey in the project area and tested to evaluate its archaeological significance. Because it consisted of limited and disturbed surficial deposits of unknown prehistoric and twentieth-century affiliation, 38 AK466 was not considered eligible for nomination to the NRHP. Archaeological investigations within the original (and subsequently altered) project area involved previously recorded site 38AK288, 38AK274, 38AK282, and 38AK283. These four sites lie outside the revised project area and will not be affected by proposed construction activities.

F/H Area Surface Enhancement Project (SU Log No. 754) This description of archaeological investigations for the proposed F/H Area Surface Enhancement Project is summarized from the report recently prepared by Sassaman and Gillam (1993). The Site Use was issued to initiate efforts at minimizing contamination to groundwater in the vicinity of two seepage basins by surface leveling, erosion control, and wetland protection. In response to these proposed activities, the SRARP conducted survey on 15 days between April 30, 1993 and June 2, 1993. Pedestrian and subsurface techniques of archaeological survey were conducted in the 200-acre F Area Seepage Basin Tract and the 280-acre H Area Seepage Basin Tract located along the northwest margin of Fourmile 
Branch. Complete survey coverage was not possible since both tracts contain hazardous waste repositories. The areas of greatest archaeological potential, however, were cleared by Savannah River Site Health Protection and made fully accessible for investigation. Twelve archaeological sites and four artifact occurrences were located during an intensive survey of these two tracts. Fieldwork included surface reconnaissance of 3.6 linear kilometers of transects, 140 shovel tests along 4.2 linear kilometers of transects, an additional 162 shovel tests at sites and occurrences, and the excavation of six $1 \times 2 \mathrm{~m}$ test units. All but one of the sites contained artifacts of the prehistoric era; the twelfth site consists of the remains of a twentieth-century home place. The historic site (38AK537) and six of the prehistoric sites (38AK57, 38AK534, 38AK536, 38AK538, 38AK540, 38AK544) consist of limited or disturbed contexts of archaeological deposits and were not considered significant. The remaining five sites (38AK146, 38AK535, 38AK539, $38 \mathrm{AK} 541$, and 38AK543) have sufficient content and integrity to yield information important to ongoing investigations into upland site use.

Central Sanitary Wastewater Treatment Facility (SU 93-18-C). This description of archaeological investigations for the proposed Central Sanitary Wastewater Treatment Facility is summarized from a report recently prepared by Stephenson and Sassaman (1993). The proposed Wastewater Facility will be built on a six-acre tract located along the northwest margin of Fourmile Branch. Associated with the Wastewater Facility is approximately 18 miles $(29 \mathrm{~km})$ of proposed trunkline routes. This extensive underground piping system will be constructed from various existing facilities on the SRS to the centralized treatment facility.

Archaeological survey of the Wastewater Facility and trunklines commenced on April 27, 1992 and continued intermittently through July 6, 1993 for a total of 16 work days. Field work included the excavation of 159 shovel tests and three $1 \times 2 \mathrm{~m}$ test units. Five previously recorded sites and one new site were investigated during the project. Two previously recorded sites, $38 \mathrm{AK} 415$ and $38 \mathrm{AK} 417$, located in the trunkline route along Fourmile Branch were revisited for intensive testing. Although both sites were occupied during the Middle and Late Woodland, artifacts densities were low with the exception of a concentrated lithic feature at 38AK415. Adverse impacts to these cultural resources can be avoided by spanning the sites during pipeline installation. One new site (38AK465), was discovered during survey of the six-acre facility footprint. This site was represented by only four chert flakes and as such was not considered archaeologically significant. Pedestrian survey and subsurface testing was conducted along the trunkline routes in areas of high probability for cultural resources and to locate three previously recorded sites (38AK 145, 38AK 419, 38AK436). None of these sites were relocated during this effort. This is mostly likely due to the ephemeral nature of the deposits at each site, which consisted of an isolated biface at 38AK436, five potsherds from the same vessel at 38AK419, and a low density scatter of lithic debris at 38AK145.

Carolina Bay Restoration Project (SU 92-29-R Amendment \#1). This Site Use project is a cooperative effort between the Savannah River Forest Station (SRFS) and the Savannah River Ecology Laboratory (SREL) to improve the wildlife habitat and enhance the natural hydrology of an isolated, eight-acre wetland designated Carolina Bay \#93. SRFS maintenance at the site will involve the damming of a historic drainage ditch, selective tree removal, controlled burning, and the use of an EPA approved herbicide to eliminate non-indigenous plants. These activities will allow natural infilling of the bay from rainfall and the subsequent regeneration of original vegetation. Following environmental restoration, the SREL will initiate a research program focusing on particular biological communities (i.e., flora, invertebrates, microorganisms, and amphibians) of the bay's ecosystem. 
In response to the Site Use Application, SRARP personnel conducted archaeological survey at Bay \#93 on three days in August of 1993. Due to the wooded condition of the project area, subsurface testing was employed to locate cultural remains. Fieldwork entailed the systematic excavation of 26 shovel test pits placed at $30 \mathrm{~m}$ intervals around the bay. This effort resulted in five positive tests. To obtain information about the size and integrity of the buried deposits, shovel test pits were excavated in a cruciform pattern at each location where materials had been recovered. Altogether 76 tests were dug in this manner resulting in the identification of two artifact occurrences and three prehistoric sites designated 38BR711, 38BR715, 38BR716. Occurrence 1 is located along the eastern edge of the bay and consists of four flakes from two tests. Occurrence 2 is located on the southeastern bay margin and consists of two flakes from two tests. Two of the archaeological sites, 38BR711 and 38BR716, are situated along the southwestern and northeastern bay edges, respectively. None of the artifacts from these sites are temporally sensitive. A Thom's Creek Punctate sherd was recovered along the northwestern bay margin at 38AK715 indicating site use during the Late Archaic period.

The significance of these sites lies in their potential to add to our understanding of prehistoric habitations at interfluvial locations. Previous settlement models on the SRS were designed with data regarding site densities and proximity to the Savannah River and its tributaries. Recent geoarchaeological investigations at bay locations (Broots et al., this report) has shown that these small wetland resources were not ignored by prehistoric peoples but instead exploited rather intensively on a seasonal if not multi-seasonal basis. This evidence for bay occupations must be considered in future regional settlement studies by focusing on such questions as chronology, site formation, structure and function, and how bay sites relate in time and space to sites along ruajor tributaries.

Borrow Pit for Par Pond Dam Repair (SU 92-47-O Amendment No. 1). In February 1993, a Site Use was issued requesting approval of a 64-acre tract near Par Pond for use as a borrow pit. Soils from this area would be used to repair an aging earthen dam that contains Par Pond, a shallow, but extensive reservoir along Lower Three Runs Creek. The project area is situated in a portion of the upland Sand Hills zone with a low potential for prehistoric sites (SRARP 1989). In addition, a review of a 1951 aerial photograph of the project area revealed no standing historic structures (U.S. Atomic Energy Commission Aerial Photograph 1951). However, the northeast portion of the proposed borrow pit fronted a small Carolina Bay. Given the possibility of buried prehistoric debris along the bay rim, nine shovel test pits were excavated at $30 \mathrm{~m}$ intervals. This effort resulted in the recovery of a sand tempered plain sherd. Using the positive test as a datum, six shovel test pits were dug at close intervals in a cruciform pattern to determine the extent of cultural materials. However, none of these tests yielded artifacts. The single sherd was subsequently recorded as an artifact occurrence.

Central Shops Sanitary Effluent Route (SU Log No. 746). The request to reroute the effluent pipeline to the central shops area along a $0.1 \mathrm{~km}$ long corridor was issued on February 22, 1993. The project location was in a low sensitivity zone for prehistoric sites and no evidence of standing historic structures were observed on the 1951 aerial photograph of the study area. SRARP personnel conducted a surface reconnaissance of the route and assessed the area as highly disturbed as a result of terrain alteration in the past by the SRS. No cultural materials were observed during the survey.

\section{Survey Results}

Sixty-six new archaeological sites were located and documented in FY93. Eighteen existing sites within survey tract boundaries were revisited to update site file 
records. A tabulation of existing and new sites by project type is provided in Table 4. Summary data on new sites are provided in Table 5.

Table 4. Tabulation of Existing Sites and New Sites by Survey Projıct Type, FY93.

\begin{tabular}{|c|c|c|c|c|c|c|}
\hline & \multicolumn{3}{|c|}{ EXISTING SITES } & \multicolumn{3}{|c|}{ NEW SITES } \\
\hline & Prehistoric & Historic & Both & Prehistoric & Historic & Both \\
\hline SITE-USE & $\begin{array}{l}\text { 38AK145 } \\
\text { 38AK146 } \\
\text { 38AK288 } \\
\text { 38AK415 } \\
\text { 38AK417 } \\
\text { 38AK419 } \\
\text { 38AK436 } \\
\text { 38AK465 }\end{array}$ & 38AKO2 & $\begin{array}{r}38 A K 287 \\
38 A K 289 \\
38 B R 57\end{array}$ & $\begin{array}{l}\text { 38AK534 } \\
38 A K 535 \\
38 A K 538 \\
38 A K 539 \\
38 A K 540 \\
\text { 38AK541 } \\
\text { 38AK543 } \\
\text { 38AK544 } \\
\text { 38BR711 } \\
\text { 38BR715 } \\
\text { 38BR716 }\end{array}$ & 38AK537 & $\begin{array}{l}\text { 38AK466 } \\
\text { 38AKS36 }\end{array}$ \\
\hline \multicolumn{7}{|l|}{ TIMBER } \\
\hline COMP & $\begin{array}{l}\text { 38BR87 } \\
\text { 38BR359 } \\
\text { 38BR384 } \\
\text { 38BR388 } \\
\text { 38BR393 }\end{array}$ & & 38BR92 & $\begin{array}{l}38 B R 689 \\
38 B R 693 \\
38 B R 694 \\
38 B R 695 \\
38 B R 696 \\
38 B R 697 \\
38 B R 699 \\
38 B R 700 \\
\text { 38AK701 } \\
\text { 38BR713 }\end{array}$ & $\begin{array}{l}\text { 38AK530 } \\
\text { 38AK531 } \\
\text { 38AK532 } \\
\text { 38AK702 } \\
\text { 38AK703 } \\
\text { 38AK704 } \\
\text { 38AK705 } \\
\text { 38BR706 } \\
\text { 38BR707 } \\
\text { 38BR708 } \\
\text { 38BR709 } \\
\text { 38BR710 } \\
\text { 38BR712 }\end{array}$ & 38BR698 \\
\hline CLEARCUTS & & & & 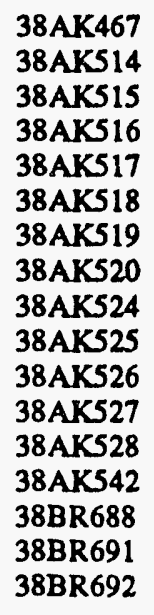 & $\begin{array}{l}\text { 38AK468 } \\
38 A K 513 \\
38 A K 521 \\
38 A K 522 \\
38 A K 523 \\
38 A K 529 \\
38 B R 685 \\
38 B R 686 \\
38 B R 687 \\
38 B R 690\end{array}$ & \\
\hline OPPORTUNISTIC & & & & & 38AK533 & \\
\hline TOTAL & 13 & 1 & 4 & 38 & 25 & 3 \\
\hline
\end{tabular}


Table 5. Data on the Extent, Depth, and Content of Sites Located ir FY93 Surveys.

\begin{tabular}{|c|c|c|c|c|c|c|c|c|}
\hline Site & Type & $\begin{array}{l}\text { Size } \\
\text { (m) }\end{array}$ & $\begin{array}{c}\text { Depth } \\
\text { (cm BS) }\end{array}$ & Methods & $\begin{array}{l}\text { Surface } \\
\text { Visibility }\end{array}$ & $\stackrel{\#}{*}$ & $\stackrel{*}{T U_{B}}$ & Components \\
\hline 38AK466 & Hist, Prehist & $50 \times 80$ & 60 & Surf., STPB & $1-25 \%$ & 10 & 0 & 20th c, Unk. Prehist. \\
\hline 38AK467 & Prehistoric & $80 \times 100$ & Unk. & Surface Recon. & $51-75$ & 0 & 0 & $\mathbf{E W}, \mathbf{M W}, \mathbf{L W}$ \\
\hline 38AK468 & Historic & $90 \times 160$ & Unk. & Surface Recon. & $51-75$ & 0 & 0 & 20th $c$ \\
\hline 38 AK 513 & Historic & $250 \times 700$ & Unk. & Surface Recon. & $51-75$ & 0 & 0 & 20th $\mathrm{c}$ \\
\hline $38 A K 514$ & Prehistoric & $15 \times 20$ & Unk. & Surf., STPs & $51-75$ & 3 & 0 & LA, MW, LW \\
\hline 38AK515 & Prehistoric & $30 \times 45$ & $\mathrm{PZ}$ & Surf., STPB & $51-75$ & 3 & 0 & Unk. Prehistoric \\
\hline $38 A K 516$ & Prehistoric & $20 \times 40$ & Unk. & Surface Recon. & $51-75$ & 0 & 0 & Unk. Prehistaric \\
\hline $38 A K 517$ & Prehistoric & $15 \times 35$ & 20 & Surf., STPs & $51-75$ & 3 & 0 & $\mathbf{E W}, \mathbf{M W}$ \\
\hline 38AK518 & Prehistoric & $35 \times 100$ & Unk. & Surface Recon. & $51 \times 75$ & 0 & 0 & LA, MW \\
\hline 38AK519 & Prehistoric & $20 \times 30$ & Unk. & Surf., STPs & $51-75$ & 3 & 0 & LA, EW \\
\hline 38 AK520 & Prehistoric & $15 \times 20$ & 20 & Surf., STPE & $51-75$ & 6 & 0 & EA, Unk, Prehist. \\
\hline $38 \mathrm{AK} 521$ & Historic & $60 \times 60$ & Unk. & Surface Recon. & $51-75$ & $\mathbf{0}$ & $\mathbf{0}$ & 19th - 20th c \\
\hline 38AK522 & Historic & $50 \times 60$ & Unk. & Surface Recon. & $51 \times 75$ & 0 & $\mathbf{0}$ & Unk. Prehist, 20th c \\
\hline 38AK523 & Historic & $40 \times 70$ & Unk. & Surface Recon. & $51 \times 75$ & 0 & 0 & 20 th c \\
\hline .8AK524 & Prehistoric & $120 \times 120$ & Unk. & Surface Recon. & $51 \times 75$ & 0 & 0 & LA, MW \\
\hline 38AK525 & Prehistoric & $50 \times 70$ & Unk. & Surface Recon. & $51 \times 75$ & 0 & 0 & Unk. Prehist, 20th c. \\
\hline 38AK526 & Prehistoric & $40 \times 50$ & Unk. & Surface Recon. & $51-76$ & 3 & 0 & Unk. Prehist. \\
\hline 38 AK527 & Prehistoric & $45 \times 90$ & Unk. & Surface Recon. & $51 \times 75$ & 0 & 0 & $\mathbf{L W}$ \\
\hline $38 A K 528$ & Prebistoric & $25 \times 30$ & Unk. & Surface Recon. & $51 \times 75$ & 0 & 0 & MW \\
\hline 38AK529 & Historic & $30 \times 45$ & Unk. & Surface Recon. & $51 \times 75$ & 0 & 0 & 19th - 20th c \\
\hline 38 AK530 & Historic & $50 \times 200$ & $\mathbf{P Z}$ & Surf., STPs & $26-50$ & 8 & 0 & 20 th $c$ \\
\hline 38AK531 & Historic & $70 \times 90$ & Unk. & Surface Recon. & $26-50$ & 0 & 0 & 20th $c$ \\
\hline 38AK532 & Historic & $100 \times 120$ & Unk. & Surface Recon. & $26-50$ & 0 & 0 & 20 th $\mathrm{c}$ \\
\hline 38AK533 & Historic & $35 \times 50$ & PZ & Surf., STP8 & $26-50$ & 9 & 0 & 20th c \\
\hline 38 AK534 & Prehistoric & 25755 & $0-5$ & Surf., STPs & $26-50$ & 12 & 0 & MW, LW \\
\hline $38 A K 535$ & Prehistoric & $75 \times 80$ & $0-50$ & Surf., STPs, TU & $1-25$ & 24 & 1 & EW, LW \\
\hline 38 AK536 & Hist, Prehist & $20 \times 45$ & $0-50$ & STPs & $26-50$ & 10 & 0 & MW, 20th c. \\
\hline 38AK537 & Historic & $30 \times 60$ & PZ & Surf., STPs & $51-76$ & 9 & 0 & 20 th $c$. \\
\hline $38 A K 538$ & Prehistoric & $10 \times 20$ & $0-50$ & STPs & $26-50$ & 11 & 0 & MW, LW \\
\hline 38AK539 & Prehistoric & $20 \times 120$ & $0-50$ & STPs, TU & $26-50$ & 14 & 1 & MW, LW \\
\hline $38 \mathrm{AK} 540$ & Prehistoric & $20 \times 50$ & $10-65$ & Surf., STPs & $26-50$ & i1 & 0 & $\mathrm{EW}, \mathrm{MW}$ \\
\hline 38AK541 & Prehistoric & $70 \times 70$ & $0-40$ & STPs, TU & $26-50$ & 29 & 1 & EW, MW, LW \\
\hline 38 AK 542 & Prehistoric & $120 \times 210$ & Unk. & Surface Recon. & $76-100$ & 0 & 0 & MW \\
\hline $38 \mathrm{AK} 543$ & Prehistoric & $30 \times 50$ & $0-60$ & STPs, TU & $1-25$ & 18 & 2 & LA, LW, Miss. \\
\hline 38 AK544 & Prehistoric & $10 \times 10$ & $0-45$ & STPs & $26-50$ & 11 & 0 & MW \\
\hline 38BR685 & Historic & $112 \times 200$ & Unk. & Surface Recon. & $51-75$ & 0 & 0 & 20th c \\
\hline 38BR686 & Historic & $120 \times 260$ & Unk. & Surface Recon. & $76-100$ & 0 & 0 & 20th c \\
\hline 38BR687 & Historic & $100 \times 200$ & Unk. & Surface Recon. & $51-75$ & 0 & 0 & 20th c \\
\hline 38BR688 & Prehistoric & $50 \times 250$ & Unk. & Surface Recon. & $51-75$ & 0 & 0 & MW, LW \\
\hline 38BR689 & Prehistoric & $110 \times 490$ & 75 & Surf., STPs & $26-51$ & 83 & 0 & LA, Unk Prehist. \\
\hline 38BR690 & Historic & $30 \times 55$ & Unk. & Surface Recon. & $51-75$ & 0 & 0 & Unk. Prehist, 20th c \\
\hline 38BR691 & Prehistoric & $80 \times 200$ & 30 & Surf., STP\&, TUs & $76-100$ & 4 & 6 & EW, MW, LW, Miss. \\
\hline 38BR692 & Prehsitoric & $50 \times 100$ & 60 & Surf., STPs & $76-100$ & 2 & 0 & MW \\
\hline 38BR693 & Prehistoric & $80 \times 140$ & 75 & STP8 & 1.25 & 44 & 0 & LW \\
\hline 38BR694 & Prebistoric & $20 \times 20$ & 70 & STPs & $1-25$ & 9 & 0 & Unk. Prehist. \\
\hline 38BR695 & Prehistroic & $10 \times 20$ & 60 & STPs & $1-25$ & 11 & 0 & Unk. Prehsit. \\
\hline 38BR696 & Prehistoric & $40 \times 50$ & 50 & STPs & $1-25$ & 22 & 0 & Uak. Prehist. \\
\hline 38BR697 & Prehistoric & $25 \times 40$ & 60 & STPs & $26-50$ & 23 & 0 & MW \\
\hline 38BR698 & Hist, Prehist & $150 \times 180$ & 75 & STPE & $1-25$ & 47 & 0 & MW, LW, 20th c \\
\hline 38BR699 & Prehistoric & $5 \times 5$ & 40 & STPs & $1-25$ & 9 & 0 & Unk. Prehist. \\
\hline 38BR700 & Prehistoric & $20 \times 70$ & 35 & STPs & $26-50$ & 22 & 0 & LA, MW \\
\hline 38BR701 & Prehistoric & $50 \times 90$ & 60 & STPs & $1-25$ & 29 & 0 & LA, MW, LW \\
\hline 38BR702 & Historic & $180 \times 300$ & PZ & STPs & $26-50$ & 16 & 0 & 20 th $\mathrm{c}$ \\
\hline 38BR703 & Historic & $30 \times 40$ & PZ & STPs & $26-50$ & 6 & 0 & 20th c \\
\hline 38BR704 & Historic & $25 \times 40$ & PZ & STPs & $26-50$ & 7 & 0 & 20 th $\mathrm{c}$ \\
\hline 38BR705 & Historic & $40 \times 40$ & PZ & STPs & $26-50$ & 7 & 0 & 20th $\mathrm{c}$ \\
\hline 38BR706 & Historic & $75 \times 110$ & Unk. & Surface Recon. & $26-50$ & 0 & 0 & 20th c \\
\hline 38BR707 & Historic & $80 \times 120$ & Unk. & Surface Recon. & $26-50$ & 0 & 0 & 20 th $\mathrm{c}$ \\
\hline 38BR708 & Historic & $30 \times 90$ & Unk. & Surface Recon. & $51-75$ & 0 & 0 & 20th $\mathrm{c}$ \\
\hline
\end{tabular}


Table 5. continued.

\begin{tabular}{|c|c|c|c|c|c|c|c|c|}
\hline $\begin{array}{l}38 B R 709 \\
\text { 38BR710 } \\
\text { 38BR711 } \\
38 B R 712 \\
38 B R 713 \\
38 B R 715 \\
\text { 38BR716 }\end{array}$ & $\begin{array}{l}\text { Historic } \\
\text { Historic } \\
\text { Prekistoric } \\
\text { Historic } \\
\text { Prehistoric } \\
\text { Prehistoric } \\
\text { Prehsitoric }\end{array}$ & $\begin{array}{l}50 \times 60 \\
50 \times 70 \\
25 \times 50 \\
30 \times 50 \\
30 \times 50 \\
65 \times 115 \\
30 \times 50\end{array}$ & $\begin{array}{l}\text { Unk. } \\
\text { Unk. } \\
50 \\
\text { Unk. } \\
50 \\
40 \\
30\end{array}$ & $\begin{array}{l}\text { Surfece Recon. } \\
\text { Surfsce Recon. } \\
\text { STPs } \\
\text { Surfece Recon. } \\
\text { Surf., STPs } \\
\text { STPs } \\
\text { STPs }\end{array}$ & $\begin{array}{r}1-25 \\
1-25 \\
0 \\
51-75 \\
26-50 \\
0 \\
0\end{array}$ & $\begin{array}{r}0 \\
0 \\
12 \\
0 \\
9 \\
15 \\
24\end{array}$ & $\begin{array}{l}0 \\
0 \\
0 \\
0 \\
0 \\
0 \\
0\end{array}$ & $\begin{array}{l}\text { 20th c } \\
\text { 19th c - 20th c } \\
\text { Unk. Prehist. } \\
\text { 20th c } \\
\text { Unk. Prehist. } \\
\text { Late Archaic } \\
\text { Unk. Prebist. }\end{array}$ \\
\hline $\begin{array}{l}\text { Surface Re } \\
\text { STPs - Sbc } \\
\text { TU - Test } \\
\text { Unk. - Un } \\
\text { EA - Early } \\
\text { MA - Mid }\end{array}$ & $\begin{array}{l}\text { on. - Surface } \\
\text { el Test Pits } \\
\text { nit } \\
\text { own } \\
\text { Irchaic } \\
\text { e Archaic }\end{array}$ & nnaiso & & $\begin{array}{l}\text { LA - Late Arch } \\
\text { EW - Early Wo } \\
\text { MW - Middle V } \\
\text { LW - Late Woo } \\
\text { Miss - Mississi } \\
\text { PZ - Plowzone }\end{array}$ & und & & & \\
\hline
\end{tabular}

A total of 1,937 acres was surveyed by the SRARP in FY93 for seven Site Use Applications, six timber compartments, and 15 clearcut stands. In addition to surface reconnaissance, 1,642 shovel tests were excavated to locate and define sites. Twentynine controlled test units were excavated to assess subsurface integrity at ten prehistoric sites.

The volume of survey work in FY93 represents a 61 percent increase over survey volume in FY92 (Table 6). The increase is largely attributed to the increase in timber compartment prescriptions issued this year, and the volume of clearcut surveys conducted. The increase in new sites for FY93 far exceeds the increase in survey volume, reflecting the more intensive level of subsurface testing employed this year.

Seven of 12 timber compartment prescriptions in issued in FY93 could not be surveyed before the end of the fiscal year. These will be carried-over to FY94 and form a substantial portion of the survey activity in the next several months. In addition, survey for the E Area project, a 1000+ acre intensive survey initiated in the summer 1993, will continue in FY 94. A large volume of clearcut surveys and other site use activities is also anticipated for FY94.

Table 6. Comparison of FY92 and FY93 Survey Results.

\begin{tabular}{lrr}
\hline & FY92 & FY93 \\
\hline Total Acres Surveyed & 1200 & 1937 \\
Site Use Applications & 16 & 7 \\
Timber Compartments Prescriptions & 0 & 5 \\
Clearcut Surveys & 3 & 15 \\
Shovel Tests & 512 & 1642 \\
Number of New Sites & 22 & 66 \\
\hline
\end{tabular}

\section{CURATION COMPLIANCE ACTTVITIES}

\section{CFR79 Compliance Activities}

36CFR79 sets forth detailed guidelines for the curation of artifacts recovered from federal lands. SRARP activities in FY93 related to the regulation focused on recuration and documentation of old collections, as well as the normal processing of incoming 
collections from various surveys detailed elsewhere in this report. Ms. Tammy Forehand and Mr. Bruce Penner joined the staff as curatorial assistants in January and March, respectively, and were detailed to the recuration and documentation effort. Mr. Steven McKettrick and Mr. John Huffman, who had previously worked on various volunteer projects under Dr. Crass, joined the staff as part-time assistants to Forehand and Penner during the summer.

Upon joining the staff, Mr. Penner upgraded the Baseline Analysis System database, merging it with the Master Curation Database to form an integrated package. The new database, dubbed the Master Baseline Database (MBD), includes calculation fields which enable the user to access numeric data in various combinations. Mr. Penner oversees the maintenance and data-entry duties associated with the MBD.

Ms. Forehand oversees the daily operations of the recuration effort. As each old collection is pulled from the shelves in the Central Curation Facility (CCF), a record is completed on the MBD. All objects are then recurated in acid-free containers, with archival media provenience and specimen tags. Acid-free hard copies of all MBD records are kept as work progresses. Two hundred and fifty thousand objects have been recurated to 36CFR79 standards by the team to date (Figure 1). This averages to 2,800 objects per day. The MBD currently holds over 3,400 records, each one of which represents one level within one provenience at a given archaeological site. When completed, the MBD will provide a single level of analysis for all objects recovered during the past twenty years of cultural resource management on the Savannah River Site. This will not only bring the collections themselves into compliance with 36CFR79, but will also constitute a research database of national significance for both prehistoric and historic archaeologists.

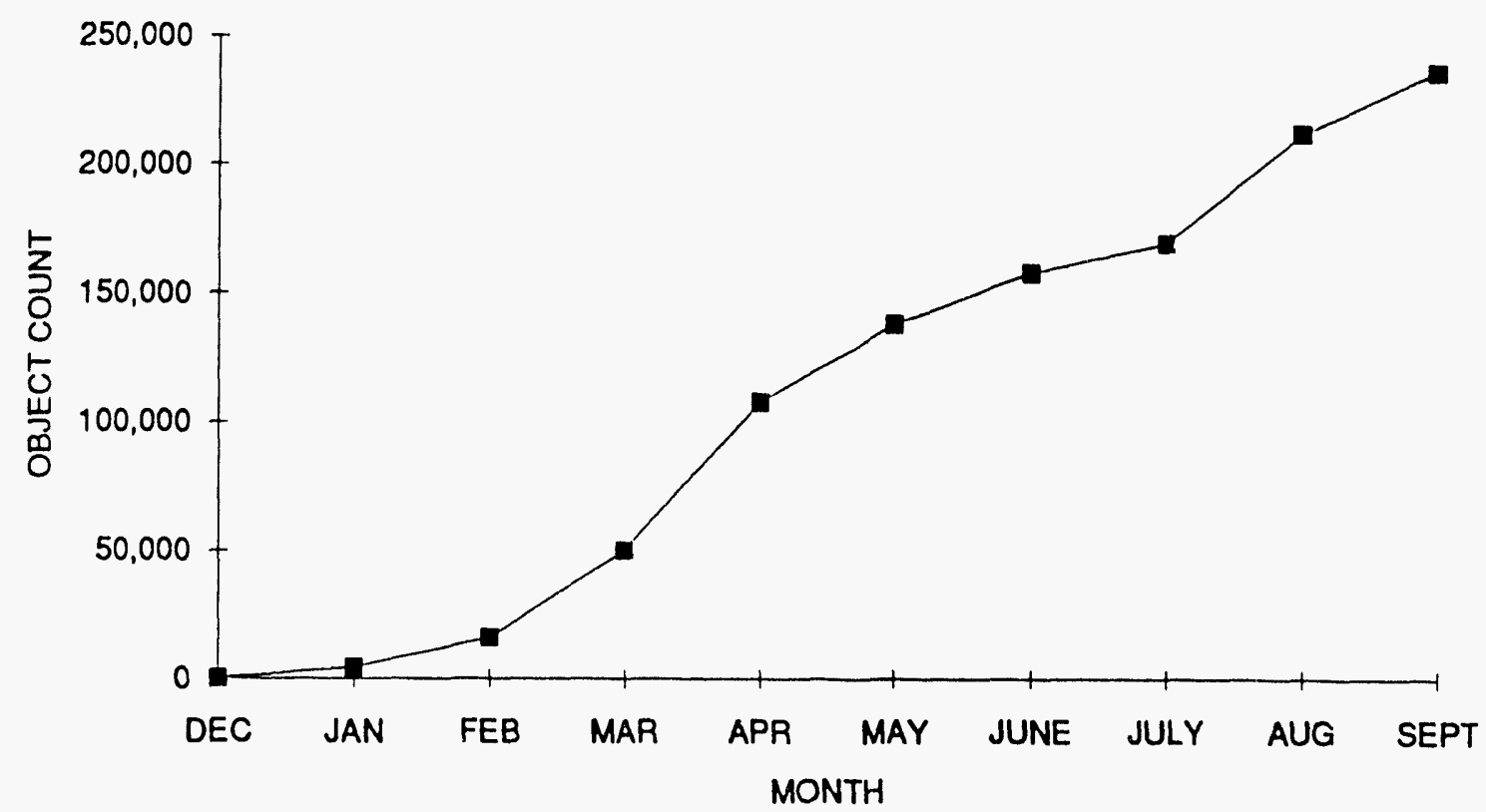

Figure 1. Cumulative line graph showing artifacts analyzed and recurated, January 1993-September 1993. 
Unfortunately, facilities enhancement has not kept pace with the recuration and documentation of collections. Despite the formulation of several detailed plans to upgrade the physical conditions under which the SRARP collections are curated (SRARP 1992) no progress has been made toward bringing the CCF into compliance with the requirements contained in 36CFR79. Aside from a shortage of dedicated curation space, there are problems with security, fire control, and humidity/temperature which compromise the long-term viability of the collections.

\section{NAGPRA Compliance Activities}

In May, the U. S. Department of the Interior issued regulations implementing the Native American Graves Protection and Repatriation Act (43CFR10, Proposed Rule). In June SRARP submitted to the National Park Service data regarding five Native American burials recovered from the Savannah River Site per the requirements of 43CFR10. These data included summary inventories as well as detailed skeletal analyses performed by Dr. Ted Rathbun of University of South Carolina-Columbia's Anthropology Department. None of the remains can be linked to any known Native American tribe. 


\title{
PART II. RESEARCH
}

\author{
RESEARCH ABSTRACTS
}

The Development of the Carolina Backcountry: Archaeological Research Domains in the Central Savannah River Valley

\author{
David Colin Crass
}

Paper presented at the Annual Meeting of the Society for Historical Archaeology, Kansas City, MO.

Recent developments in comparative frontier historiography have important implications for historical archaeology research designs. Issues including boundary maintenance, the rise of local elites, the development of hinterland economic networks, environmental history, and core/periphery relationships offer avenues for the anthropological investigation of historic-period frontiers. These issues are brought to bear on recent research on late-eighteenth and early-nineteenth century archaeological sites on the U.S. Department of Energy's Savannah River Site (SRS), a three hundred-square mile federal reservation located on the Atlantic Upper Coastal Plain. Preliminary findîngs are presented and contrasted to current perspectives based on archival research, and future research plans are presented.

\section{Consumer Patterns at Three Early- to Mid-20th Century Farmsteads in Barnwell County, South Carolina}

\section{Charles J. Rinehart and Melanie Cabak}

Paper presented at the 26th Annual Conference of the Society for Historical Archaeology, Kansas City, MO.

In the winter of 1991-1992, the Savannah River Archaeological Research Program excavated three early- to mid-20th-century farmsteads near New Ellenton, South Carolina. Primary and secondary documentation showed that there were a variety of tenure types present at all three sites. Tenant and yeoman farmer consumer patterns are investigated by analyzing artifact assemblages from the three sites. These findings are then compared to historical consumer studies of farm families in the southeastern United States. The role personal choice played in the daily lives of tenant and yeoman farmers at the Barnwell County sites is also addressed.

\section{Oral History at the Savannah River Site}

\section{Tonya A. Browder, David Colin Crass, and Richard David Brooks}

Paper presented at the Annual Meeting of the South Carolina Historical Association, Columbia, SC.

In 1951, the Atomic Energy Commission (AEC, now the U. S. Department of Energy) announced the construction of the Savannah River Plant in Aiken County, S. C. The 300square-mile area chosen for the plant included numerous farms, as well as the towns of Dunbarton and Ellenton, and several small hamlets, including Myers Mill, Bush, and Leigh. The residents of these towns and farms were bought out by the AEC; however, 
many of them stayed in the Aiken area. In 1990 the Savannah River Archaeological Research Program (SRARP), a division of the South Carolina Institute of Archaeology and Anthropology, began a community history project in order to capture the memories of these former residents. To date over 50 informants have furnished information on small-town and rural life in early 20th century South Carolina. Topic areas which have been targeted include home life, occupations, yard proxemics, church and social life, and consumer behavior. In addition, many informants have furnished pictures, diaries, and other artifacts which help illustrate a life-way that has virtually disappeared from the modern American landscape. The results of this research are currently being used to help interpret three early-twentieth century farmsteads which were excavated by archaeologists in 1991, and will be fully published in the SRARP Heritage Series in late 1993. This paper is the first report on the results of this project.

\title{
Turtlecrawl Point: Lessons from an Inundated Prehistoric Site in Boca Ciega Bay, Florida
}

\author{
Albert C. Goodyear, Sam B. Upchurch, and Mark J. Brooks \\ Paper presented at the Annual Meeting of the \\ Florida Anthropological Society, Clearwater Beach, FL
}

The presence of salt water inundated prehistoric sites dating from the early to the late Holocene is well documented in Tampa Bay and related bays. These sites were discovered in a derived condition as parts of fills and spoil piles due to the dredging activity of the 1960s. One site, Turtlecrawl Point, was studied and reported on in a preliminary way in 1980 . Since that time, additional data have been gathered related to radiocarbon dating of shell tools and Venus mercenaria fragments thought to represent shellfish exploitation, and more detailed petrologic data on lithic raw material types and origins. Based on projectile point types and other lithic tool forms, there is evidence for a Bolen occupation (ca. 10,000-9,000 B.P.), a Middle Archaic Newnan occupation (ca. 6,000 B.P.) and a Late Archaic occupation (5,000-4,000 B.P.) based on Putnam points and radiocarbon dated shell tools. Quahog clam shells, virtually all broken, are common from the site and based on radiocarbon dates appear to date within the last 3,500 years. No time sensitive artifacts have been found later than Late Archaic, suggesting the site was closed to terrestrial occupation at about the time of the modern sea level position. The clam shell, if humanly modified, may represent shellfish procurement by people dwelling in nearby terrestrial sites. The site is significant as it shows the changing terrestrial and marine environments of the Tampa Bay region due to the affect of rising sea level.

\section{Holocene Changes in Wetland Ponds in the Upper Coastal Plain of South Carolina}

\section{Barbara E. Taylor and Mark J. Brooks}

Paper presented at the American Society of Limnology and Oceanography and Society of Wetland Scientists in the symposium Paleolimnology and Global Environmental Change, Edmonton, Alberta, Canada.

Most of the isolated wetland ponds in the Upper Coastal Plain of southeastern North America dry out annually. For ponds on the U. S. Department of Energy's Savannah River Site, this hydrologic pattern may be a recent phenomenon. Historic/modern era land clearing, wetland draining, and agricultural practices accelerated rates of upland 
erosion. Sediment cores from 11 ponds document infilling of the shallow basins. While the present character of the ponds is probably attributable most directly to human activities of the late historic/modern era, long and short-term variation in Holocene climate and vegetation undoubtedly produced earlier hydro-biological changes in the ponds. Radiocarbon dates on charcoal from the sediments, in conjunction with historical, archaeological, and geological data, are used to infer timing and magnitude of basin infilling. The implications of these data for the evolving ecological community, including humans, are considered within the broader context of regional environmental changes, whether anthropogenically or climatically induced.

\section{At the Center of Peripheries: \\ Late Woodland Persistence in the Interior Coastal Plain of Georgia}

\section{Keith Stephenson and Adam King}

Paper presented in symposium at the 49th Annual Meeting of the Southeastern Archaeological Conference, Little Rock, AR.

Swift Creek settlements in south-central Georgia became increasingly dispersed and impermanent after A.D. 400. This trend continued as a tradition of cord marked pottery appeared in the area after A.D. 800, marking the local beginning of the Late Woodland period. Simultaneously, in the surrounding area, Mississippian culture began to emerge without exerting much, if any, influence on the south-central Georgia population. A persistence of cord marked pottery and the absence of Mississippian traits suggest an imperviousness to surrounding developments. These local forms of cultural conservatism or resistance have parallels in, and are perhaps directly related to, developments in northcentral Florida.

\section{Hartford Revisited: Surface Reconnaissance at a Swift Creek Village}

Keith Stephenson and Frankie Snow

Paper presented at the 1993 Spring Meeting of the Society for Georgia Archaeology Red Top Mountain State Park, GA

Previous archaeological investigations during 1988-89 at the Hartford site (9PU1) in south-central Georgia primarily concentrated on a Swift Creek mound where a rich submound midden was exposed. Excavations revealed evidence of a premound structure with a large central pit that contained an excellently preserved and diverse assemblage of subsistence remains. Limited testing also was conducted in an adjacent Swift Creek village midden. Comparisons of ceramic and lithic artifacts from the submound midden and the village indicate a temporal difference between occupations in the two areas. During the winter of 1993, the site was plowed exposing a well delineated midden containing discrete refuse deposits of primarily river mussel shell and other faunal remains along with sherds and lithics. These refuse deposits are attributed to episodes of individual household dumping. Together, the midden and refuse deposits form an arc approximately $110 \times 70 \mathrm{~m}$ open to the east-southeast. This midden arc conforms to community patterns noted at other regional Middle Woodland sites. 


\section{Swift Creek Designs: A Tool For Monitoring Interaction}

Frankie Snow and Keith Stephenson

Invited paper presented at the Conference on Swift Creek Culture, Macon, GA.

The presence of decoration on prehistoric ceramic vessels is generally believed to be a means of symbolically conveying information. Previous researchers have approached the analysis of pottery designs from various theoretical perspectives to address questions concerning social affiliation, political alliances, ideology, and regional interaction. The pottery type recognized as Swift Creek with its elaborately carved paddle stamped designs is probably the best surviving product of Middle Woodland material culture in the interior Southeast from which we can gain a fuller understanding of social and regional processes. Through the study of Swift Creek designs, a data base has been established that demonstrates an intensely interconnected set of sites that formed a regional interaction sphere. This study is founded on the empirical evidence that a common paddle produced the designs even though sherds bearing the same imprission may occur on sites separated by a considerable distance. Because of the unique quality of Swift Creek designs, it is possible to plot spheres of interaction. Settlement patterns can be established from this data based on a narrower time interval than is currently available. Additionally, design distribution has the potential to shed light on the seasonal movement of groups, trade between areas, or kinship affiliations.

\section{Raiders, Traders, and Refugees in the Mid-Holocene of the American Southeast \\ Kenneth E. Sassaman \\ Paper presented in symposium at the 49th Annual Meeting of the Southeastern Archaeological Conference, Little Rock, AR.}

Demographic responses to mid-Holocene environmental degradation set in motion processes that transformed the social and political landscapes of the Southeast. Raiding and other forms of intergroup conflict arose as populations negotiated the use of increasingly circumscribed habitats. Trading intensified to avoid strife and to develop alliances for minimizing risk. Certain groups sought relief from strife and demands on their labor, using alliance networks as routes of refuge. Skeletal data, evidence for exchange, and patterns of population movement all point toward a dynamic, complex history of integration and disintegration among some of the most disregarded populations of North American prehistory.

\section{Understanding Pre-Columbian Native Encounters}

\section{Michael S. Nassaney and Kenneth E. Sassaman}

Paper presented in symposium at the 49th Annual Meeting of the Southeastern Archaeological Conference, Little Rock, AR.

In the 1940s and 1950s Southeastern archaeologists (e.g., Joseph Caldwell and James Ford, among others) often speculated on panregional patterns of cultural interaction and influence. The rise of scientific archaeology in the 1960s forestalled such speculation by debasing the concepts of migration and diffusion and substituting neoevolutionary 
Savannah River Archaeological Research Program

concepts that caused us to artificially bound systems. We argue for large spatial frameworks that allow us to redress, with new theoretical insights, the patterns our forbears began to document. Sociopolitical issues surrounding archaeological practice can help to explain historical changes in scales of analysis.

\title{
The Social Contradictions of Traditional and Innovative Cooking Technology in the Prehistoric American Southeast
}

Kenneth E. Sassaman

Invited paper presented in symposium at the 58th Annual Meeting of the Society for American Archaeology, Pittsburgh, PA.

The earliest pottery in North America emerged in the midst of a soapstone cooking technology that was central to the establishment and maintenance of exchange alliances in the Savannah River Valley. The new technology, along with innovations to improve thermal efficiency, were slowly adopted by groups that produced soapstone tools. Stylistic innovations and alternative alliances arose to offset the social contradictions imposed by such resistance. Eventually, the widespread use of pottery contributed to a strategy of fissioning that undermined soapstone trading networks. Patterns to these sociopolitical processes are evident in the local and regional records of early ceramic vessels.

\section{Adaptive Flexibility in the Morrow Mountain Phase of the Middle Archaic Period}

\author{
Kenneth E. Sassaman
}

Paper published in South Carolina Antiquities 23:31-41.

The Middle Archaic archaeological record of the South Carolina Piedmont is much like that of any other piedmont area of the South Atlantic Slope-it consists of ubiquitous, small sites in varied locations with sparse, low diversity artifact assemblages. Current explanations for these patterns include high residential mobility, expedient technology, generalized subsistence, and open social networks. These factors can be articulated and redressed in a model of adaptive flexibility that highlights those aspects of Middle Archaic organization that assured long-term stability in the region. Surface assemblages from Morrow Mountain phase sites in the Piedmont portion of the Savannah River Valley lend empirical support to the model. In contrast, the Middle Archaic record of the Coastal Plain reflects changes that may have stemmed from extralocal influences and/or indigenous processes, but in any event, served to transform Morrow Mountain societies into more differentiated, less stable forms of human organization.

\section{RESEARCH NOTES}

\section{The Savannah River Backcountry}

In May 1993, Crass, Penner, and Forehand began a multi-year research project in Beech Island, South Carolina. While Crass and Penner serve as Co-Principle Investigators, Forehand serves as Field Supervisor, overseeing a mixed team of professional and volunteer excavators. The project aims to recreate the cultural and natural environment of New Windsor Township, a frontier settlement colonized by Swiss, 
Germans, and others in the late 1730s located approximately 12 miles upstream of the Savannah River Site. To date four archiaeological sites dating from ca. 1740-1800 have been located. One of these, 38AK615, is the subject of ongoing excavations. Nearly 50 subsurface features, including middens, post holes, hearths, and a possible privy, have been exposed through a combination of machine-stripping and shovel scraping at the site. Over 7,000 objects have been analyzed to date.

38BR615 appears to include a post-in-ground house with wattle-and-daub walls, as well as two and possibly three outbuildings. The site is significant in several respects. It has yielded extensive collections of fauna and botanical remains, which are extremely rare on Colonial period sites due to the acidic soil of the Upper Coastal Plain. The assemblage also includes a large number of ceramics from England, China, and the European continent. These and other artifact classes will be useful in reconstrucing frontier trade relationships. Finally, the middens at the site are encapsulated in discrete pit features. Although the analysis results are preliminary, these middens appear to date to specific, rather short time spans. Thus, it may be possible to tie sub-assemblages to specific occupants of the site, once the archival research is completed (see below).

Aside from its research potential, the New Windsor Township Survey will be useful in devising survey methods which adequately locate and sample Colonial period sites on the SRS. To date only one such site has been located and excavated, although given the available primary archival documentation, there should be several hundred located here. Further, the New Windsor Township Survey will allow us to frame research questions geared to the database which such sites yield. Thus, research in Beech Island should aid substantially in cultural resource management activities at the SRS.

\section{Graduate Research in Primary Documents}

Richard Brooks and David Crass supervised a doctoral student at the University of South Carolina-Columbia. Research consisted of a comprehensive inventory of all eighteenth and early nineteenth century primary documents such as wills, probate inventories, and land plats relating to New Windsor Township. These results will be included in upcoming reports on the New Windsor Township Survey project.

\section{National Science Foundation Gifted Scholars Program}

SRARP continued participation this year in the National Science Foundation's Young Scholars Program, under which high school students who intend to pursue a career in the sciences serve as research assistants at SRS. David Crass served as mentor to Preston Dyches, a high school senior from South Aiken High School. Dyches participated in fieldwork at 38AK615, analyzed ceramics from surface collections ranging in date from ca. 1735-1800, and reported his findings in a presented paper.

\section{Woodrow Wilson Boyhood Home (9RI432)}

David Crass and George Lewis supervised excavations at the Woodrow Wilson Boyhood Home (9RI432) in Augusta, GA through the first of FY93. The weekend excavations, which were carried out by members of the Augusta Archaeological Society, were intended to assess the integrity of yard deposits dating from the mid-nineteenth century. Isolated patches of intact mid-nineteenth deposits were located in the side and front yards of the house. The crawlspace under the servant's quarters yielded a rich and diverse assemblage relating to the third quarter of the nineteenth century, as well as important architectural data critical to the rehabilitation of the home. The results of this 
Savannah River Archaeological Research Program

project were reported in a preliminary report published by the Augusta Archaeology Society under the authorship of Crass and Lewis.

\section{Midden Point Project}

The SRARP was fortunate to have a summer intern from the U.S. Department of Energy's Student Research Participation program administered by the Oak Ridge Institute for Science and Education. Sherry Leis of Beloit College in Wisconsin joined the SRARP staff for ten weeks in 1993 to undertake analysis of materials salvaged from the Midden Point site (9BK113) in Burke County, Georgia. Despite limited experience in archaeological research, Ms. Leis quickly developed expertise in lithic and ceramic analysis, cataloging tens of thousands of objects from this rich Late Archaic period site. Combined with the ongoing efforts of Tammy Forehand of the SRARP staff, the results of Ms. Leis' work will be reported fully in a chapter of the forthcoming volume Late Archaic Shell Midden Archaeology in South Carolina and Georgia to be published by the Archaeological Society of South Carolina.

\section{Mims Point Project}

In Fiscal Year 1992, the SRARP, through SCIAA, entered into a cost-share agreement with the United States Forest Service to provide archaeological testing at the Mims Point site on the Sumter National Forest in Edgefield County, South Carolina. This effort documented the existence of an extensive assemblage of architectural remains, thermal features, and human interments dating from the Middle Archaic, Late Archaic, and Late Woodland periods. To ensure long-term protection to this once-looted site, the USFS agreed to continue limited field investigations on an annual basis. A second season of field investigations was conducted in late September 1993 under the direction of Kenneth E. Sassaman. Expansion of the 1992 excavation block to the north and east documented the edge of the primary midden area and served to identify several Late Archaic pit features associated with a habitation structure discovered in the first season. Further excavations to the south of this area revealed more Late Archaic pit features, including two basin hearths, as well as additional postholes believed to be affiliated with a second structure. Excavations to the west revealed the continuation of an arcuate trench-like feature dating to the Late Woodland period (ca. A.D. 700). First identified in 1992 , this feature was originally believed to be a refuse-filled trough associated with Late Woodland domestic activities. Work this year showed that the trench extended well below the shell refuse, and was especially deep in two pits tentatively identified as postholes. It therefore appears that the feature is a wall trench to a circular Late Woodland structure some $9-10 \mathrm{~m}$ in diameter. Central support posts were not identified, but we did locate a small basin hearth in the approximate center of the structure. Future investigations will be designed to locate other features associated with this structure. In the meantime, a draft report of the 1992 field season was completed in June 1993 and will be released jointly by the SRARP and the USFS.

\section{Clark Hill Reservoir Survey}

Daniel T. Elliott of the LAMAR Institute was awarded funds by the SRARP to assist with his research on the archaeological records from the Clark Hill Reservoir survey conducted from 1948-1951 by the National Park Service's River Basin Survey. Although the survey located several hundred sites and included extensive testing at the famous Lake Spring site, little of this work was published. Elliott traveled to the Smithsonian Institution in Washington, D.C. to examine the records and collections from this work in an effort to make basic documentation available to the contemporary archaeological community. This included data on site location, temporal components, 
artifact types, and provenience for over 200 sites. A draft of Elliott's report was issued in September 1993. The final report, including video documentation of the artifact collections, will be jointly released by the LAMAR Institute and SRARP.

\section{Investigations at a Middle Mississippian Site on the Georgia Coastal Plain}

During September, Keith Stephenson and Frankie Snow continued archaeological investigations at the Sandy Hammock site (9PU10). The site is situated on what appe rs to be an active point bar along the lower Ocmulgee River. The distribution of cultural material conforms to the shape of the landform, which encompasses an area of approximately $52,000 \mathrm{~m}^{2}$. Prior work at the site involved contour mapping; the excavation of 297 shovel test pits spaced $10 \mathrm{~m}$ apart on a grid; the excavation of two $1 \times 1$ $\mathrm{m}$ and nine $2 \times 2 \mathrm{~m}$ test units; and two small block excavations. Detailed artifact-class analyses and contextual data strongly indicate that site use was intensive during the Late Archaic, Middle Woodland (Deptford), Middle Mississippian (Etowah IV/Savannah), and Late Woodland periods, with minor occupations during the late Middle Woodland (Swift Creek and Napier) and Late Mississippian (Lamar) periods. Shovel test data have enabled us to delineate horizontally discrete components at the site, thereby providing spatial and temporal information about site use. In the areas of highest elevation where components overlap, deposits are found in well defined strata with diagnostic artifacts following a downward sequence from Mississippian $(10-30 \mathrm{~cm} \mathrm{BS})$ to Middle Woodland (30-50 cm BS) to Late Archaic (60-80 cm BS). In topographically low areas, such as along the river margin where Mississippian and Late Woodland artifacts are found, there is an absence of component superposition with mixed deposits occurring to a depth of 60 cm BS.

This year, work has focused on obtaining soil cores from different locations at the site. These cores consist of continuous sediment columns collected in $5 \mathrm{~cm}$ increments to a depth of at least $150 \mathrm{~cm}$. The resulting grain size data, along with the chronological controls provided by the archaeology, will be used in addressing questions pertaining to landform evolution, which in turn will enhance our understanding of site formation processes. On a higher level, these results will provide comparative data about sediment signatures by depositional environment for the SRS sediment data base being compiled by Mark Brooks of the SRARP (SRARP 1991:35).

\section{Middle Woodland Research in South Georgia}

Stephenson and Snow also returned this year to the Middle Woodland period Hartford site (9PU1) to map and survey a rich, Swift Creek village midden that had been exposed during agricultural activities. Previous investigations at the site concentrated on the architectural remains of a large ceremonial Swift Creek structure that was intentionally burned and covered with a low earthen mound. Within this structure was evidence of ritual feasting probably related to mortuary ceremonies. A second mound was present at the site until the 1930s when it was destroyed during road construction. This mound most likely served as a place of interment for the deceased of high status. Our recent work in the village midden revealed the presence of a planned community that was occupied probably no more than 50 years. The midden forms an arc about one-half hectare opening to the southeast. Included within the midden are twenty, discrete scatters of dense shell deposits that also contain sherds, lithics, and well preserved faunal remains. These localized deposits are hypothesized refuse dumps from individual households. The village most likely was composed of households that together formed an interacting community of related families. 
Contextual information indicates that Hartford was an important center during the Early Swift Creek period when the sub-mound structure was in use. Intensive use of the site continued during the subsequent Middle Swift Creek period, but its regional importance seems to have lessened. Although these separate occupations represent cultural continuity, there are obvious differences in community patterning and site function. The presence of two mounds along with the excavated evidence of a submound ceremonial structure related to communal feasting indicates a ritual use of the site and possibly some form of social inequality during the Early Swift Creek period. Subsequent use of the site during the Middle Swift Creek period resulted in planned community that reveals no evidence of ritual activity in the form of special purpose structures or burial earthen tumuli. Food preparation and waste discard during this later occupation probably was a household related activity as opposed to the communally organized feasts of the earlier occupation. The residential pattern and the absence of elite status architecture suggests that sociopolitical organization was egalitarian. The results of these investigations have important implications for the sociopolitical organization, variation in site function, and regional settlement of Swift Creek populations in the Coastal Plain of Georgia. In addition, the site report will provide important comparative information about Middle Woodland societies in the southeast, their local manifestations on the SRS, and in particular the contemporaneous Lewis West site (38AK228) in the central Savannah River area.

\section{RESEARCH FELLOWSHIPS AND GRANTS}

Fellowship and grant funding from the SRARP was made available in FY93 for projects involving both prehistoric and historic-period research, as well the related fields of history, geography, geology, paleoecology, ethnohistory, rural sociology, and American studies. Resident fellowships were open to advanced graduate students, as well as professionals. Grants were offered for the directed research of students and professionals.

Fellowship funding provides the resources and environment necessary for advanced graduate students and professionals to pursue major research projects. The research purview for fellowships is intentionally broad to allow for a variety of analytical and theoretical approaches to regional-scale or comparative research. There are thus no geographical restrictions to fellowship research, although research serving to advance knowledge about the middle Savannah River Valley in its regional or global contexts is highly encouraged.

SRARP Grants provide for research pertaining directly to the prehistory and history of the middle Savannah River Valley. Graduate student research proposals are especially encouraged, but any projects complementing the research and management missions of the SRARP are potentially fundable.

Grant rccipients during FY93 inclicied John Grant of the Department of Geology, Brown University who pursued research on upland wetlands on the SRS (see report below), and Daniel T. Eliiott of the LAMAR Institute, who travelled to the Smithsonian Institution to study collections and records from the Clark Hill survey (see report above).

In November 1993, a second group of scholars will begin their research programs. The five recipients and their project titles include Mitchell $R$. Childress, Garrow and Associates, Inc. (Prehistoric Archaeology of the Upper Cumberland River Drainage, Tennessee); Adam King, Department of Anthropology, Pennsylvania State University, (The Context of the Southeastern Ceremonial Complex at the Etowah Site); Robert D. Mitchell, Department of Geography, University of Maryland at College Park, and Warren 
R. Hofstra, Department of History, Shenandoah University (Townscape of Winchester, Virginia: The Morphology of a Market Town in the 18th-Century Backcountry); James R. Purdue, Curator of Zoology, Illinois State Museum (Estimating the Hunting Catchment of Southeastern Indians using Ancient DNA recovered from Archaeological Deer).

\title{
RESEARCH REPORTS
}

\section{UPLAND WETLANDS INVESTIGATION OF PLEISTOCENE-HOLOCENE ENVIRONMENTAL CHANGE ON THE SRS: 1993}

\author{
Mark J. Brooks \\ Barbara E. Taylor \\ Savannah River Ecology Laboratory, University of Georgia \\ John A. Grant \\ Department of Geological Sciences, Brown University \\ Evelyn Gaiser \\ Savannah River Ecology Laboratory, University of Georgia
}

Understanding the history of environmental changes in a landscape is critical to understanding the history of human occupation of that landscape. In the Upper Coastal Plain of South Carolina, studies on the evolution of the alluvial terraces of the Savannah River have contributed substantially to our knowledge of fluvial environments as loci of prehistoric activity in the region (Brooks and Sassaman 1990; Sassaman et al. 1990). Much less is known about the upland landscape, particularly the xeric interfluves of the Aiken Plateau where surface water is limited largely, at least currently, to a sporadic distribution of Carolina bays and other isolated, temporary ponds. Because prehistoric populations tended to track surface water, the archaeological record of their activities can be employed in monitoring, both spatially and stratigraphically/chronologically, an evolving landscape. Further, changes over time in the nature and intensity of prehistoric activities, as reflected by the archaeological record, may be indicative of the changing environmental character of that landscape, e.g., the distribution of surface water.

Carolina bays and other isolated wetland ponds are an important feature of the upland landscape on the Savannah River Site. These shallow ponds, because of their hydrologic responsiveness to short-term variation in climate, may serve as sensitive barometers of paleoenvironmental conditions. Useful information about southeastern paleoenvironments has been extracted from peat cores of Carolina bays elsewhere in the Coastal Plain by Frey (1951), Whitehead (1981), Watts (1980), and others. However, in this portion of the Coastal Plain, the shallow basins, the hydrologies of the ponds, and the warm, moist climate are not conducive to accumulation or preservation of organic materials. In reconnaissance studies on the Savannah River Site, we were unable to find bays with peaty sediments. We were thus challenged to apply other techniques for reading the record of paleoenvironmental conditions.

We report here on initial results from coordinated studies on changes in basin morphology and indicators of ecological conditions in Carolina bays on the Savannah River Site. We mapped sediment composition and stratigraphy by taking cores and using round-penetrating radar (GPR) at seven bays. We established time scales for aepositional processes on the rim of Flamingo Bay through archaeological dating. Also 
at Flamingo Bay, we established time scales for depositional processes at the center of the basin using radiocarbon dates. In exploratory studies, we discovered siliceous microfossils of diatoms, sponges, and vascular plants that can serve as indicators of ecological conditions in and around the pond. Our initial results indicate that the Carolina bays have changed substantially during the Holocene. These results, in light of a growing body of evidence suggesting a strong association between prehistoric archaeological sites and Carolina bays, demand that these wetland features of the landscape be factored into models of regional settlement variability. Tangentially, our initial results also contribute to the evidence concerning ages and origins of Carolina bays.

\section{THE STUDY AREA}

The United States Department of Energy's Savannah River Site (SRS) is a 803 $\mathrm{km}^{2}$ reserve in the Upper Coastal Plain of South Carolina (Figure 1). There are at least 194 Carolina bays and other isolated wetlands located on the site (based on Schalles et al. 1989; unpublished analyses by Wein and Kirkman located $>50$ additional bays). The ponds range in area from $0.5-50$ ha in area. More than a third of the ponds showed evidence of agricultural use during the historic era, and about half were altered hydrologically by ditches (analysis of 1951 aerial photographs by Wein and Kirkman). During a 1990 study of 88 ponds on the SRS, $>90 \%$ of the ponds dried at some time during the year (DeBiase, Taylor, and Mahoney, unpublished data).

\section{SRS Sampling Design}

From the bays and other isolated wetlands shown in Figure 1, twenty-three bays were selected for further consideration. Although qualities such as large size and long hydroperiod were considered, the primary criteria were duration, intensity, and diversity of ecological studies conducted by the Savannah River Ecology Laboratory (SREL). We felt that detailed studies of the modern character of the bays would provide useful baselines against which inferred variation in the past could be compared.

Based on archaeological data maintained by the Savannah River Archaeological Research Program, all known archaeological sites within a $5 \mathrm{~km}$ radius of each of the twenty-three bays were plotted. Because both bays and archaeological sites are more sparsely and discretely distributed on the upland (Aiken Plateau) than on the alluvial terraces, we felt that assessing relationships between archaeological sites and environmental processes might be easier for the upland bays. Each of the eleven upland bays remaining in our sample was visited between November 1992 and May 1993 to evaluate its archaeological potential and accessibility to GPR equipment. The seven bays selected for further study were Flamingo Bay (\#3 according to Shields et al. 1982), Bay 58, the paired Mona (66) and Woodward (67) Bays, the paired Craig Pond (77) and Sarracenia Bay (78), and Thunder Bay (83) (Figure 1). The GPR survey, directed by Grant, was conducted at the seven bays, emphasizing Flamingo, from June 22-July 2, 1993.

\section{FLAMINGO BAY}

Because it is one of the best known bays, ecologically, Flamingo Bay was selected for the first detailed study. The water level at Flamingo Bay fluctuates widely (30-160 cm), but it has not dried completely during the period of our record (most of 1986-1993). This variability is great enough that the pond presently supports an aquatic community typical of a temporary pond (Mahoney et al. 1990), and it lacks fish. The bay was not ditched during the historic era, but its rim and margins were cleared and 


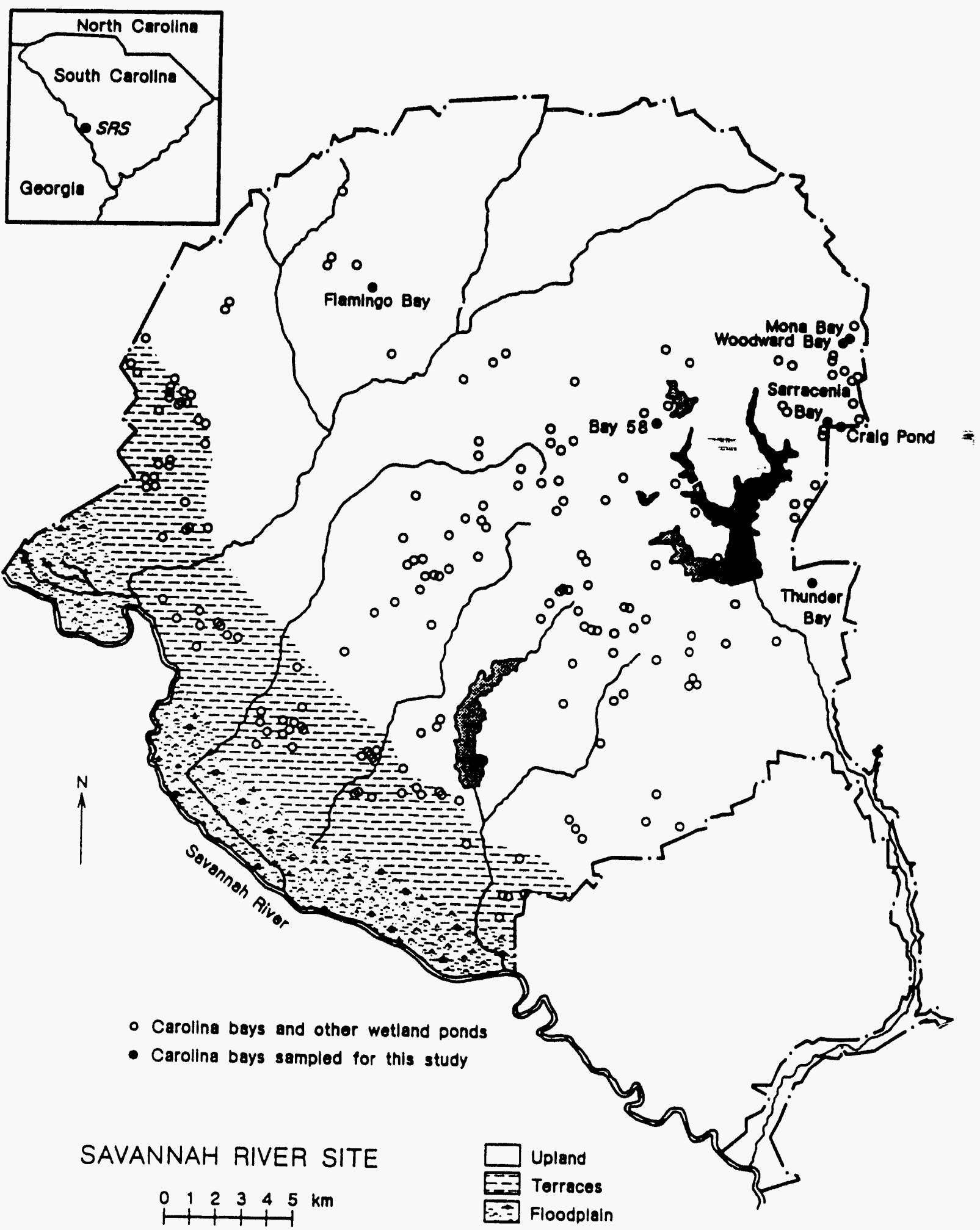

Figure 1. Location of the SRS and seven study bays. 
cultivated extensively. These observations from 1943 and 1951 aerial photographs were verified by our field investigations.

\section{Archaeological Survey and Site Testing}

Based on our understanding of prehistoric subsistence-settlement variability on the SRS and vicinity (e. g., Brooks and Sassaman 1990; Brooks et al. 1990; Sassaman et al. 1990), we targeted the east-southeast sand rim of Flamingo Bay for initial investigation. The sand rim in the area investigated is currently in mature pine plantation with a sparse understory of shrubs and vines. Basinward, down slope to the west in the area of fluctuating water level, water-tolerant hardwoods (sweetgum [Liquidamber styraciflua], red maple [Acer rubrum], and blackgum [Nyssa sylvatica biflora]) assume dominance. Further toward the interior lies a zone dominated by panic grasses (Panicum sp.) with occasional blackgum and button bush (Cephalanthus occidentalis). The central pool of the basin is dominated by submerged and floating aquatic macrophytes, including smart-weed (Polygonum sp.) and American lotus (Nelumbo lutea).

Using standardized field methods for site discovery and definition that are fully described in the Savannah River Archaeological Research Program's Annual Report (1990), we discovered site 38AK469 and delineated its vertical and horizontal "extent through a cruciform pattern of shovel tests (Figure 2). The $0.30 \times 0.30 \mathrm{~m}$ shovel tests were excavated to a depth of 0.60 to $1.20 \mathrm{~m}$, depending upon the depth of the archaeological deposits and/or the depth at which the B/C soil horizon (see below) was encountered. Artifacts were recovered by passing all excavated soil through $1 / 4$-inch mesh screen. Based on the shovel test data (artifact density, assemblage diversity, and temporally diagnostic artifacts), a $1 \times 2 \mathrm{~m}$ test unit (Provenience 25--see below) was

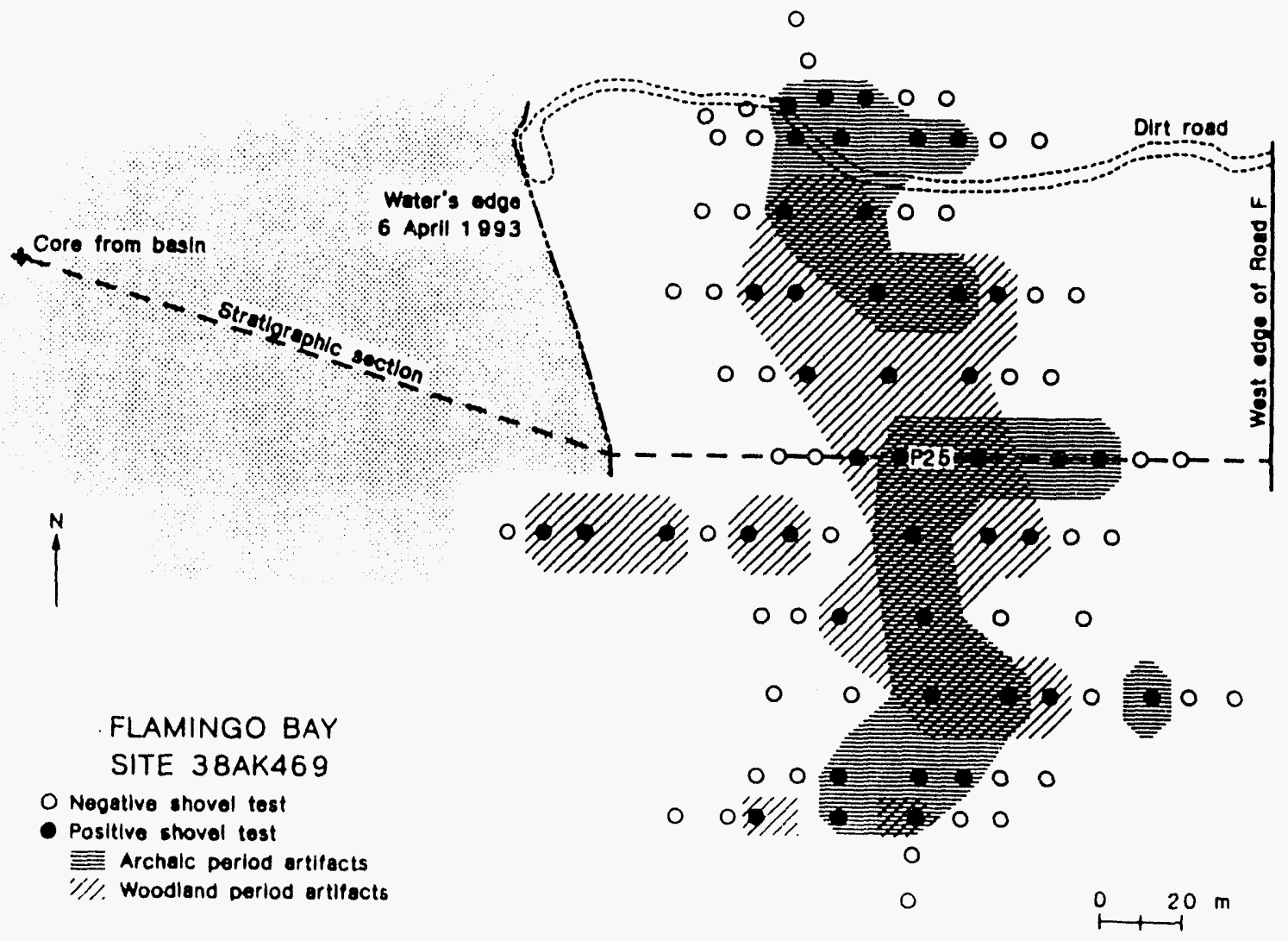

Figure 2. Site map of 38AK469. 
excavated to a depth of $105 \mathrm{~cm}$ in order to obtain more detailed assemblage, chronologic and stratigraphic data. Sediment samples from Provenience 25 and soil auger data were then obtained for rim-basin stratigraphic correlation and for use in groundtruthing during the subsequent GPR survey.

\section{Stratigraphy and Chronology}

Rim. The north-south oriented, roughly crescent-shaped site, 38AK469, follows the crest of the sand rim for a distance of $186 \mathrm{~m}$ and varies from 30 to $130 \mathrm{~m}$ east-west. Based on the shovel test data, the site exhibits horizontal as well as vertical stratigraphy (Figure 2). Loci containing only Archaic period components (ca. 9500-4000 B.P.) are found at the extreme north and south ends of the site and on the eastern side of the site toward the exterior margin of the rim. Archaic and sparse Late Woodland, and possibly Mississippian, artifacts are present in the central portion of the site along the rim crest. Only the later Woodland/Mississippian materials (ca. 1200-500 B.P.) are present in the west-central portion of the site, where they extend downslope to the west into the basin, and, at one location, to the high water line recorded in April, 1993.

Archaeological and sedimentological stratigraphic data from Provenience 25 are summarized in Figure 3. In the absence of observable deposttional or cultural stratigraphy, excavation below the plow zone was by $10 \mathrm{~cm}$ arbitrary levels, starting at 25 $\mathrm{cm}$ below present ground surface and extending to a total depth of $105 \mathrm{~cm}$. All excavated soil was passed through 1/4 inch mesh screen. An effort was made to locate and record precisely the vertical and horizontal positions of artifacts that are temporally diagnostic and/or larger than $\sim 2.5 \mathrm{~cm}$. Temporally diagnostic artifacts are essential for establishing precise chronological controls, and the larger artifacts are good indicators of buried surfaces because they are less likely to have been displaced vertically by occupational and post-depositional processes (e.g., Stockton 1973; Hughes and Lampert 1977; Baker 1978; Ferring 1986; Brooks and Sassaman 1990; Brooks et al. 1990).

A continuous sediment column was obtained at $5 \mathrm{~cm}$ increments from the central area of the west wall of Provenience 25. From the base of the excavation at $-105 \mathrm{~cm}$, sampling continued at $20 \mathrm{~cm}$ increments with a standard soil auger to a total depth of $245 \mathrm{~cm}$, well into the highly weathered (oxidized orange and red) sandy silt and clay B/C soil horizon that forms the aquiclude/aquitard beneath the sandy rim and basin fill of Flamingo Bay. The sedimentological field methods and laboratory analyses are described in Brooks and Sassaman (1990).

Sedimentological data for the upper $1 \mathrm{~m}$ of artifact-bearing deposits at Provenience 25 (Figure 3 ) indicate several small peaks that are best defined in the coarse sand-size range. The peak at $20-25 \mathrm{~cm}$ below present ground surface represents the contact at the base of the modern plow zone. The contact was clearly visible in the field. The peak at $45-55 \mathrm{~cm}$ coincides with an Early Archaic, Kirk phase surface (ca. 95008300 B.P.; Sassaman et al. 1990), as determined by artifacts plotted in situ at $53 \mathrm{~cm}$ below present ground surface. The peak at $70-80 \mathrm{~cm}$ may also represent a buried surface, but this is not confirmed by archaeological data. Variation in the $80-100 \mathrm{~cm}$ depth range is not readily interpretable on sedimentological grounds.

Downslope and 30-70 m west of Provenience 25, lag deposits of fine to medium pebble-sized quartz gravel lie on top of the weathered and scoured B/C soil horizon. These deposits, which were roughly delineated by additional shovel and soil auger testing, run parallel to the rim and modern shoreline. They are interpreted as lower shoreface deposits indicative of a buried paleoshoreline(s). 


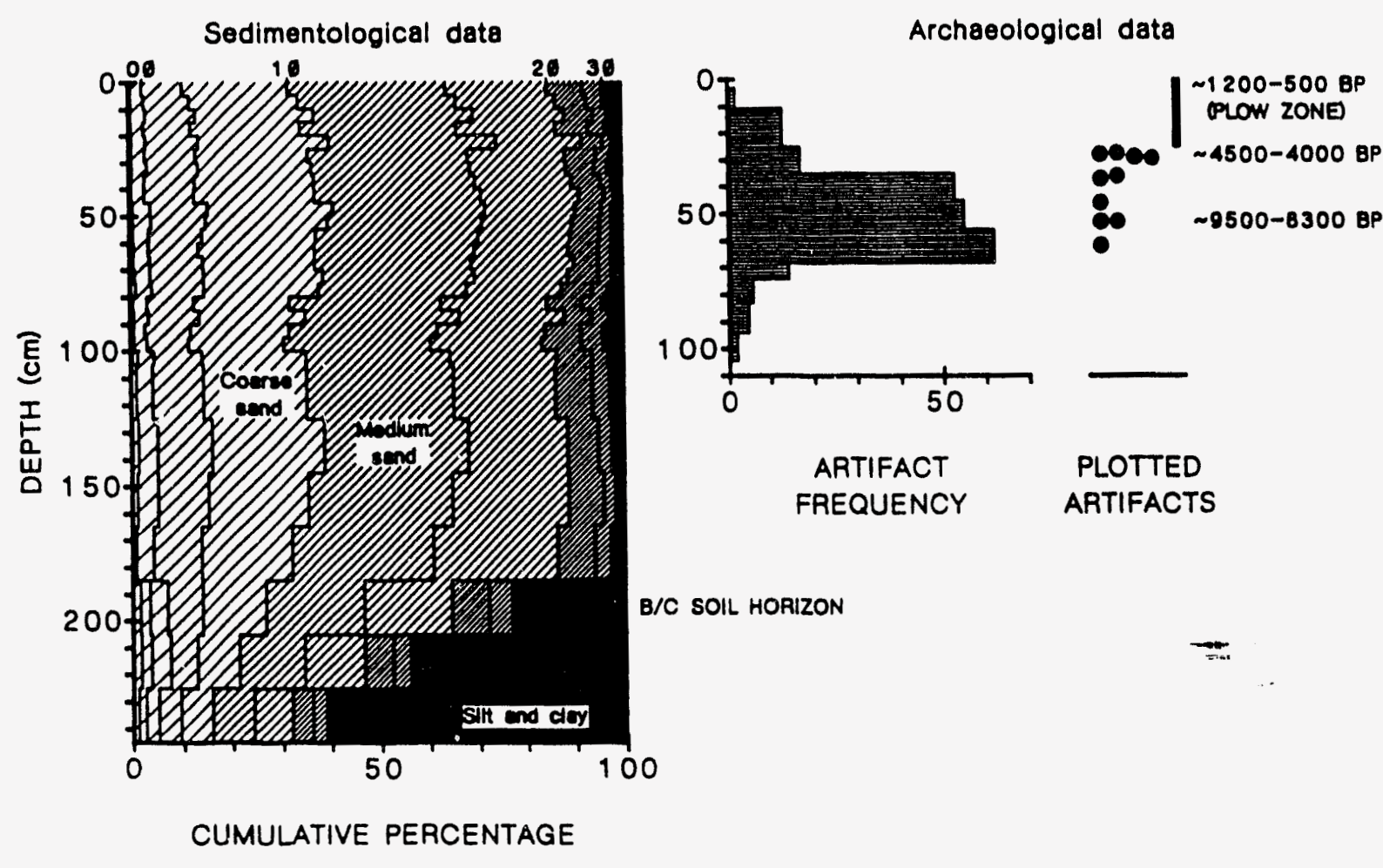

Figure 3. Stratigraphy of the southeast sand rim of Flamingo Bay at site 38AK469, Provenience 25.

The upper $25 \mathrm{~cm}$ (plow zone) of Provenience 25 represents a mixed archaeological context. Temporally diagnostic artifacts give a minimum date of ca. 1200500 B.P. (Figure 3). The higher frequency of artifacts in the $25-68 \mathrm{~cm}$ depth range, coupled with the plotted artifacts indicating buried surfaces, suggests that the $25-68 \mathrm{~cm}$ depth range represents a relatively stable, slowly accreting surface. From the temporally diagnostic artifacts recovered at $25-35 \mathrm{~cm}$ and at $53 \mathrm{~cm}$ (Figure 3), we estimate sediment accumulation rates of 0.03-0.07 mm/yr. Presumably, the sediment peak at $45-55 \mathrm{~cm}$ represents a period of comparative stability with respect to surface accretion. As indicated by the dated context at $53 \mathrm{~cm}$, this occurred between 9500 and 8300 years ago. The sparse archaeological materials in the $68-105 \mathrm{~cm}$ depth range are all small and consist almost exclusively of lithic debitage. These data are interpreted as reflecting vertical displacement from the stable, slowly accreting surface above.

We tentatively conclude that the southeastern rim sediments represent aeolian over upper shoreface deposition. While the sediments are fairly coarse-grained, with graphic means of $1.139-1.304 \emptyset$ for the upper $70 \mathrm{~cm}$, the inclusive graphic standard deviations of $0.628-0.723 \emptyset$ are well within the range $(0.50-0.80 \emptyset)$ reported for most inland dunes (e.g., Friedman and Sanders 1978:73). Possibly most important, the geomorphic setting of the area reasonably precludes alluvial or colluvial deposition. The fairly coarse grain size of the sediments suggests that aeolian transport onto the rim would have occurred over short distances, perhaps by saltation from an upper shoreface. 
The series of minor sediment peaks and valleys in the $70-100 \mathrm{~cm}$ range (Figure 3) may represent an upper shoreface depositional environment, with the overlying sediments that contain the archaeological deposits representing a westward/basinward prograding "dune" over the upper shoreface sediments. The archaeological, horizontal stratigraphic data above, as well as evidence for buried lower shoreface deposits indicative of a paleoshoreline(s), support this interpretation.

Finally, with reference to the sedimentological stratigraphic data in Figure 3, the morphology of the sediment curves in the $105-185 \mathrm{~cm}$ depth range is virtually identical to those of the corresponding grain-size classes in the 0-105 depth range. The only obvious difference is the finer resolution of the $0-105 \mathrm{~cm}$ depth range due to the smaller sampling interval of $5 \mathrm{~cm}$. It may be that repetitive, stacked sequences are involved, such that the $105-185 \mathrm{~cm}$ depth range may represent an incipient upper shoreface-dune sequence associated with the early phases of basin formation/deflation and orientation. Given this scenario, the 0-105 cm depth range would have been associated with a rise in water level that presumably corresponded with a high energy, open water phase during the early Holocene, and possibly much earlier, followed by a transition to lower energy conditions associated with the westward/basinward progradation of the southeastern sand rim and basin infilling.

Basin. A sediment core for charcoal analysis was taken near the center of the Flamingo Bay basin with a Dutch gouge auger on 19 November 1992 . Impenetrable basal material (B/C soil horizon) was encountered at $1 \mathrm{~m}$, and the length of the extracted sediment core was $94 \mathrm{~cm}$. The core was divided into sections according to color and texture of the sediments. The quartz sand-dominated sediments were processed by gentle wet sieving. Material retained on 500- and 250-micron sieves was air-dried, then examined under a dissecting microscope. Charcoal fragments, typically $0.5-1 \mathrm{~mm}$ in length, were removed with fine forceps. Three of the seven of the core sections yielded enough charcoal (5-10 $\mathrm{mg}$ ) for AMS radiocarbon dates.

Radiocarbon analyses were performed by Beta Analytic/ETH Accelerator Laboratory. Dates in uncorrected radiocarbon years B.P. from the upper half of the core are 2550 65 (Beta-59955/ETH-10071), 3055 \pm 70 (Beta-59956/ETH-10072), and $4505 \pm 75$ (Beta-59957/ETH-10073). The dates are presented graphically in Figure 4, with the vertical bars showing the depth range of the core section from which the charcoal was extracted and the horizontal bars showing the standard deviations of the dates. The dates indicate low rates of sediment accumulation $(0.1-0.3 \mathrm{~mm} / \mathrm{yr})$ in the basin of Flamingo Bay. Applying similar rates to the lower half of the core yields a date of $\sim 10,000 \mathrm{yr}$ B.P. for the deepest sediments.

Rim-Basin Correlation. The stratigraphical and chronological data from Flamingo Bay are summarized in Figure 5, where the vertical lines show auger locations and the vertical positions and ages of strata are estimated from archacological dates at the starred location on the rim (Provenience 25) and from radiocarbon dates at the starred location in the basin. From the archaeological and radiocarbon dates, we infer that significant deposition has occurred both on the rim and in the basin of Flamingo Bay during the Holocene. The modern pond has a maximum inundated area of $\sim 6$ ha and a depth of $1.6 \mathrm{~m}$. Extrapolating dimensions from the stratigraphic section map (Figure 5), we estimate that the inundated basin was much larger $(\sim 10-14 \mathrm{ha})$ and deeper $(\sim 2.4-3 \mathrm{~m})$ in the Early Archaic period (early Holocene). 


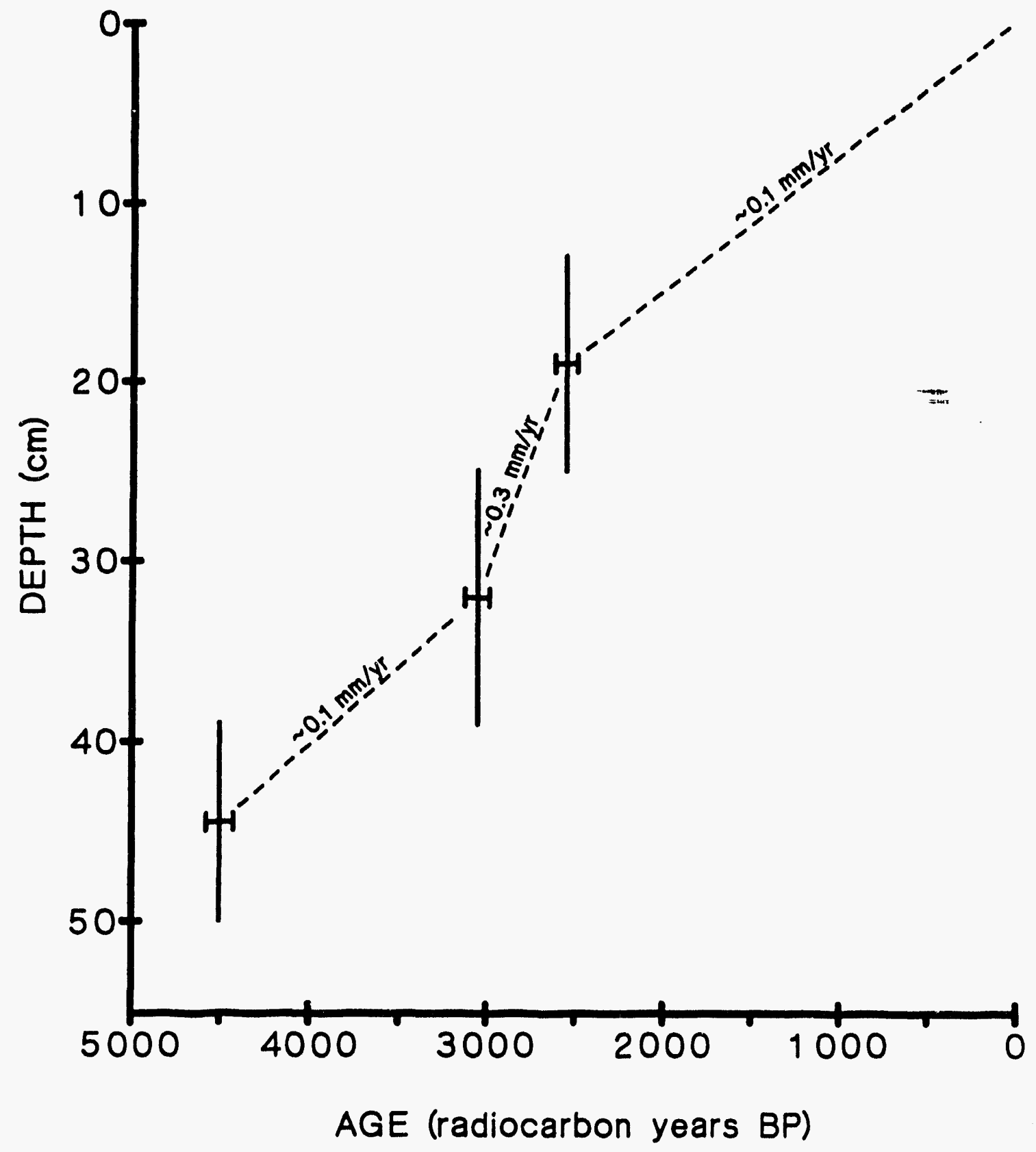

Figure 4. Radiocarbon dates of charcoal from the deepest part of the basin at Flamingo Bay. 


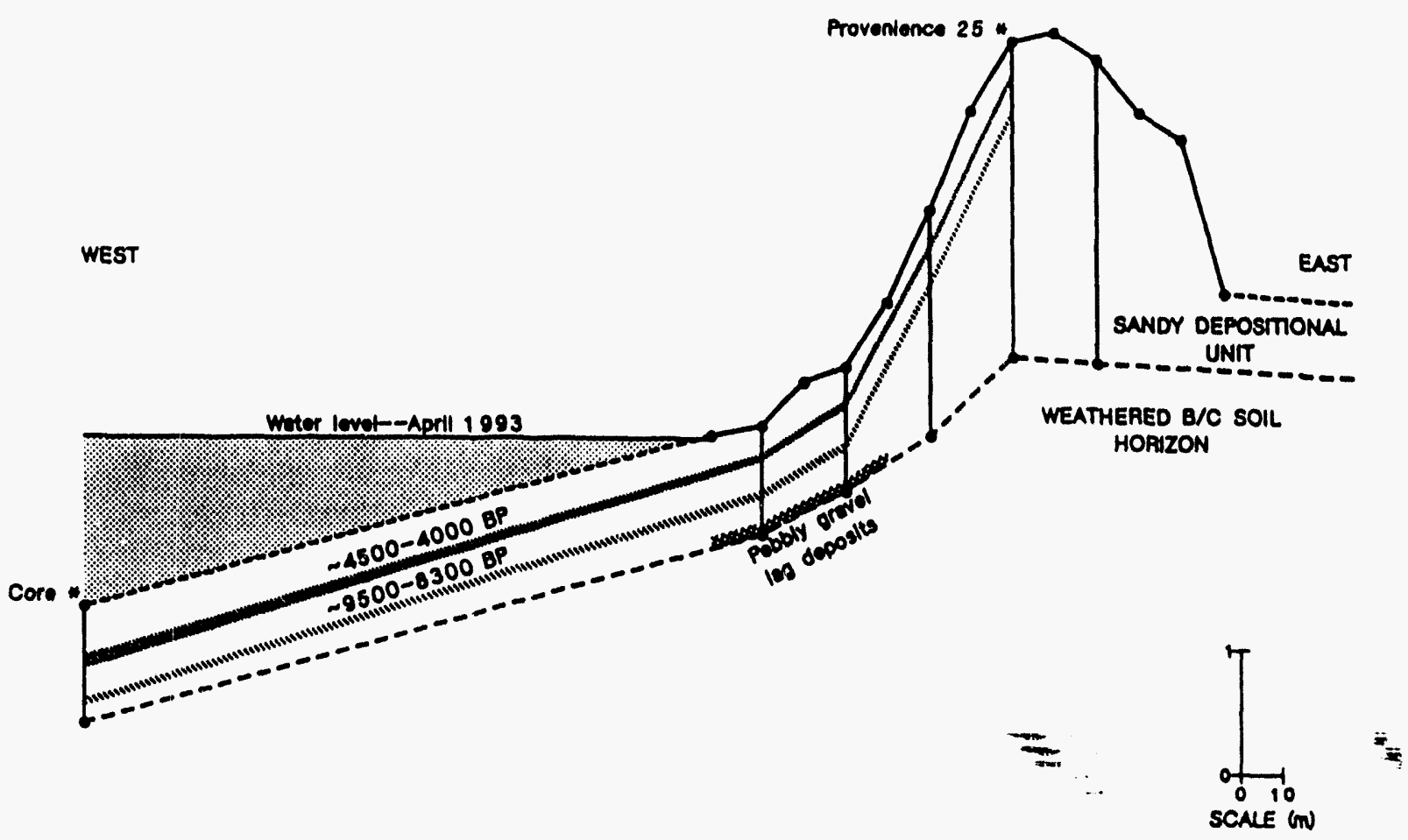

Figure 5. Stratigraphic section through the southeast sand rim of Flamingo Bay.

\section{GROUND PENETRATING RADAR SURVEY}

Ground Penetrating Radar (GPR) provides a tool for rapid, non-invasive probing of the shallow subsurface to depths of several meters. It is well suited for imaging the pedogenic and depositional stratigraphy around Carolina bays on the SRS. A transmitted bipolar radar pulse is reflected off dielectric contrasts in the subsurface and detected by an antenna receiver. As the received signal is processed and displayed during a continuous scan across a surface, reflectors are displayed and generally reproduce the underlying stratigraphy, although several properties of the GPR can cause distortion in the data. When these characteristics of GPR data are recognized and accounted for, the instrument can help to define stratigraphy over broad areas with minimal groundtruthing.

Radar deployment around Carolina bays at the SRS was geared toward understanding their origin, subsequent sedimentary evolution, and human occupational history. Terrain in the study areas around the seven Carolina bays was generally flat to slightly inclined, and vegetation cover ranged from open pine forest to woodland with dense undergrowth. Data were collected using a Geophysical Survey System SIR-3 analogue GPR with a $500 \mathrm{mHz}$ transducer with a sensitivity setting of 800 (unitless) and a two-way pulse travel-time of 50 ns. Initial activity with the GPR entailed evaluation of dielectric properties in the subsurface. Test pits $(25-125 \mathrm{~cm}$ deep) were excavated at each bay to identify soil and sedimentologic properties. The bottom of each pit was then lined with metal plates and backfilled, and the GPR was run across and adjacent to the filled pit. This process allowed derivation of the dielectric constant and pulse travel times for both disturbed and undisturbed material above the buried plates, including: 1) the zone disrupted by historic/modern era cultivation $(0-25-30 \mathrm{~cm}$ below present ground surface), 
2) depths previously identified at 38AK469, Provenience 25, as corresponding to subtle grain-size variations ( $-45-55 \mathrm{~cm}$ and $-70-80 \mathrm{~cm}--$ see Figure 3$)$, and 3 ) fine-grained bay fill. Dielectric constants (unitless) and pulse travel times in the vicinity of all bays were fairly uniform within a given sedimentary environment. Calculated values for the dielectric constant and one way pulse travel tines are, respectively: 1) approximately 7.8 and $2.8 \mathrm{~ns} / \mathrm{ft}$ for the $25-30 \mathrm{~cm}$ thick cultivated zone, 2) $3.2-5.3$ and $1.8-2.3 \mathrm{~ns} / \mathrm{ft}$ throughout the well-sorted, dry, coarse-medium sand below the cultivation zone and extending to depths of several meters, and 3) 10 and $3.2 \mathrm{~ns} / \mathrm{ft}$ in finer, wet to saturated, bay-filling sediments. Using these values, the depth to reflectors identified in subsequent radar transects can be calculated. Following the constraint of subsurface dielectric properties at each bay, GPR data were obtained along intersecting transects.

First order observations regarding the seven bays can be made from the preliminary GPR data. First, there may be a basal stratigraphic marker horizon in the form of a relict pedogenic $B / C$ horizon that is common to all of the bays. Occurrence of this horizon remains to be confirmed at two of the bays and must be distinguished from more incipient pedogenic B horizons in some areas. If confirmed, such a regional marker horizon would help to constrain ages and causes of bay formation. Second, distributions of shallow GPR reflectors between paired bays display no obvious evidence of bay transgression with time or age differences between bays. Third, overall stratigraphic complexity is similar at each of the bays examined to first order. The general sequence observed around the bays appears comparable to that in surrounding regions, implying that bay formation did not significantly alter pre-existing regional stratigraphy. Fourth, most of the topography associated with the bay rims appears to be related to locally greater thicknesses of a regional sand body. It is not known whether this sand layer extends into the interiors of the bays; however, GPR reflectors do suggest a basinward dip of a stratigraphic layer around the interior of some bays. Fifth, less prominent reflectors corresponding to subtle changes in subsurface grain size and/or buried prehistoric occupation surfaces may exist, but were not conclusively identified. Finally, there is considerable second order variability in the stratigraphy from bay to bay. Presumably, this second order variability reflects differences in the histories of the individual bays, while the first order similarities reflect regional processes.

\section{SILICEOUS MICROFOSSILS IN PALEOENVIRONMENTAL RECONSTRUCTION}

The fossil remains of organisms in sediments of depositional environments are frequently used to reconstruct changes in physical, chemical, and biological features of the environment. To be useful in this regard, an organism must meet three criteria: 1) ecological sensitivity, 2) taxonomically diagnostic morphology, and 3) preservation in abundance in the sediments.

Three groups of microfossils that meet these criteria from sediments of Carolina bays on the SRS are diatoms, vascular plant phytoliths, and sponge spicules. Although not yet quantified, these microfossils are present in the Flamingo Bay sediments. Using methods described by Battarbee (1986) for the extraction of diatoms and Pearsall (1989) for phytoliths, Gaiser recovered species of both from a Dutch gouge auger core obtained just landward of the waterline depicted in Figure 5. Sponge spicules were observed by Taylor under a dissecting microscope in material from the sediment core obtained near the center of the Flamingo Bay basin (Figure 5). Pollen and other organic materials do not seem to preserve well in the sandy abrasive sediments of the SRS bays.

Initial surveys of diatoms on the SRS have identified four taxa uniquely tolerant of drying conditions (Gaiser 1993). Their presence in bay sediment cores may be useful in inferring past soil moisture. The presence of sponge spicules would indicate periods of 
inundation. If it is possible to use plant phytoliths diagnostically in these upland coastal plain areas, their record in the sediments could provide information on locations of past vegetational and hydrologic gradients. Future studies of the siliceous microfossil assemblages from Flamingo Bay and the other ponds will be conducted by Gaiser.

\section{DISCUSSION AND CONCLUSIONS}

Although we obtained preliminary ground-penetrating radar and archaeological data from six other bays on the SRS, our most detailed data bearing on questions of age, origin, and evolution of Carolina bays are from Flamingo Bay. We tentatively conclude that the sediments of the southeast rim represent aeolian over upper shoreface deposition and that the sand rim accreted very slowly during the Holocene. These features are consistent with the prevailing hypothesis (Kaczorowski 1977) that Carolina bays are deflationary features formed and oriented by paleo-winds from the west. While the sorting values of sediments on the sand rim support the idea of aeolian deposition, the comparative coarseness of the sediments, when contrasted with those from other depositional environments on the SRS and vicinity, suggests that the fines in the area of the rim examined were winnowed out, either by aeolian or upper shoreface processes. Additional comparative analyses of sediments obtained from the exterior of the rim and from the interior, central basin should shed light on the issue. The archaeological inferences about the location of buried surfaces are corroborated by subtle variation in grain-size composition up the sediment column.

The Holocene changes in pond size and depth almost certainly affected the hydroperiod of the pond. Ecologically, Flamingo Bay now functions as a semipermanent wetland pond, and it lacks the fish that are characteristic in permanent pond communities. We infer from the changes in pond size and depth and from a decrease in the intensity of human activity at Flamingo Bay (38AK469) that the pond began to assume its modern seasonal character after 4000 B.P. during the late Holocene. While social factors in settlement variability can not be ruled out, the more intensive Archaic period occupations, as indicated by types of artifacts present, comparatively high artifact densities, and assemblage diversity, do suggest that the pond was a more valuable source of water during the early to mid-Holocene. Its greater value may have been due to greater predictability of water in the pond, or it may have been due to greater scarcity of upland aquatic habitat. If climate in the early Holocene was cooler but not much drier, the larger, deeper pond would have been likely to fluctuate less widely, and it may have supported a permanent pond fauna, including substantial populations of fish and turtles. Relatively high densities of mesic floral (e.g., acoms, hickory nuts) and faunal (e.g., deer, turkey, squirrel) subsistence resources might have occurred on the rim crest and slopes. Under this scenario, we can imagine a landscape containing many more permanent or semi-permanent lakes than presently exist on the SRS. Alternatively, if the climate were drier, the attraction of Flamingo Bay may have been its uniqueness.

We believe that these shallow ponds, because of their hydrologic responsiveness to short-term variation, can serve as sensitive barometers of paleoenvironmental conditions. Our challenge is discovering how to read these barometers.

Acknowledgments. The authors thank David Crass, Tammy Forehand and Bruce Penner of the SRARP staff, Adrienne Debiase (SREL), and Kevin Eberhard (WSRC) for volunteering their time for fieldwork. Very special thanks are extended to Kevin, who took annual leave to participate, for his astute observations of the archaeological and geological records and for his insight into environmental processes. 


\section{PART III. PUBLIC EDUCATION}

The public education program of the SRARP expanded greatly in FY93 with the addition of full-time Heritage Education specialist Mary Inkrot. Now with a proactive approach to public education, the SRARP is able to meet the needs of more school and civic groups than ever before. In addition to the long-standing on-site volunteer excavations at Tinker Creek, the SRARP program offered in FY93 programs of fieldwork at off-site locations, increased involvement with South Carolina Archaeology Week and the Summer Teachers Institute, and a variety of heritage education programs. The Community History Project also intensified in FY93, as did SRARP involvement with avocational archaeological societies.

\section{Heritage Education}

Outreach efforts towards school children constitutes a new direction in the SRARP heritage education program. This includes not only classroom visits and direct interaction with students, but initiatives to reach teachers who in turn would be able to promote archaeology education throughout the academic year. With the beginning of the 1993-94 school year, outreach efforts to local schools increased. For the month of September, approximately 750 school children at various grade levels heard presentations and participated in hands-on activities related to archaeology.

In June, staff members Richard Brooks, Mark Brooks, Ken Sassaman, and David Crass served as instructors of the the South Carolina Institute of Archaeology and Anthropology Summer Teachers Institute, held in Columbia for teachers across the state. In addition, Mary Inkrot assisted with the management of the nine day-long class. The SRARP anticipates offering their own version of the class at the University of South Carolina-Aiken for teachers in Aiken, Barnwell, and Allendale counties during FY94.

\section{Outreach to the General Public}

In the past year, SRARP staff reached broader audiences of both adults and children by participating at public events such as Heritage Day at Beech Island as well as the largest outreach effort of the year, Archaeology Week. Staff members also responded to requests of local civic groups who requested presentations on archaeology.

The annual celebration of Earth Day provided the SRARP with an excellent forum for archaeology outreach. The SRARP joined personnel from all over the Savannah River Site to prepare for the 1993 event. This year, SRARP participation increased by having a display, along with exhibiting unprovenienced artifacts, at both the on-site celebration and the off-site celebration at Lake Olmsted in Augusta, Georgia. The display consisted of photographs and quotes from the Community History Project concerning the towns of Dunbarton and Meyers Mill. SRARP also produced a six page educator's packet on archaeology which was distributed through 500 Earth Day Resource Kits to local school teachers.

A brochure, entitled Hidden Heritage: Exploring Past Lifeways at the Savannah River Site, was prepared in late FY93 for distribution in FY94. Designed for the general public, it describes the basic techniques of archaeology and briefly describes the culture periods of South Carolina. The brochure also presents information on the SRARP and its three-fold mission of compliance, research, and education.

The SRARP continued its involvement with South Carolina Archaeology Week held September 25-0ctober 2, 1993. Several staff members served on various working 
committees in preparation for the state-wide event. A major initiative for Archaeology Week was the production of an educator's packet designed to encourage middle school teachers to introduce the subject of archaeology to their students. Mary Inkrot and Elizabeth Collins of SCIAA received a mini-grant from the South Carolina Humanities Council to produce and distribute the 12 page packet. Assisting as a consultant on the project was David Crass. The packet, Archaeology In The Classroom, contains: a brief explanation of archaeology and of the cultures of South Carolina; three activity sheets, readily adaptable to use in the classrooms as well as a vocabulary list; and resource lists to promote the effective teaching of archaeology. These resources entailed bibliographies, newsletters, and curriculum materials, as well as locations of archaeological sites and of various museums with archaeology related exhibitions for class visits. Distribution of the packet totaled over 1,300 copies to schools throughout the state.

In conjunction with the packet, David Crass and Mary Inkrot along with Martha Zierden, archaeologist at the Charleston Museum, taught an in-service session for 32 teachers in Charleston County schools. In addition, the SRARP presented a display and distributed the educator's packets at the in-service for Aiken County schools.

Finally, SRARP sponsored several displays which were on view during all or part of Archaeology Week at the Nancy Carson Library in North Augusta, Aiken County Library in Aiken, DOE Headquarters at the Savannah River Site, NationsBank in New Ellenton, and the Sixth Annual Fall Field Day at Santee State Park.

\section{Community History Project}

For the past two years, the SRARP Community History Project has collected both oral and written interviews from people who once lived on the SRS. Our efforts initially concentrate on Dunbarton and Meyers Mill, two of the communities that were in the area and were abandoned, in 1951, when the Atomic Energy Commission (AEC) acquired the land for the SRS in Aiken, Barnwell, and Allendale Counties, South Carolina. The collected data will be presented in the SRARP Heritage Education Series Monograph Number 1, entitled Memories of Home: Dunbarton and Meyers Mill Remembered, which is currently in press. The demand for the Dunbarton and Meyers Mill book has been very encouraging. As of 1 September 1993, 453 people have filled out order forms for this first volume. Following publication of the Dunbarton/Meyers Mill volume, three further volumes will be prepared. These volumes will discuss the towns of Ellenton and Leigh, where a large lumber mill constructed banana boxes; other small communities within the bounds of the present-day SRS, such as Sleepy Hollow, Skinface, and Hawthorne; and the construction and impact of the AEC weapons complex on traditional lifeways in the area.

As part of the interview process, a standardized questionnaire is sent out to former residents of the Savannah River Site area by family, church or town groups. The questionnaire serves a dual purpose: it allows out-of-state residents the opportunity to participate in the project and the mailed in questionnaire responses are used to help formulate a prioritized list of potential local informants. For each interview, a more detailed standardized questionnaire is used, which focuses information on what homes, schools, and churches were like in the area. In addition, informants are asked about the types of jobs that were available in the area, the kinds of food they ate, and activities they participated in for entertainment.

At each interview, the informant browses through an album of historical photographs from the communities. This has proved to be very helpful in getting an 
informant to focus on specific areas of interest, and also serves as a kind of memory stimulus, much as family albums always seem to spark animated discussions of times past. These historical photographs were collected from informants. During the interview, any memorabilia the informant might have-photographs, family histories, diaries, letters, and business records-are reviewed. Hundreds of family photographs, school, church, and business records, and family diaries have been acquired for inclusion into the upcorring monographs.

In 1992, the number of returned questionnaires was 68, and the total number of indepth interviews conducted was twenty-nine. Overall, 97 oral and written questionnaires have been collected, with 28 of the informants providing both oral and written interviews. In 1993, 98 written questionnaires have been collected and 24 interviews have been conducted. In all, 223 oral and written questionnaires have been collected, with 53 of the informants providing both oral and written interviews.

In addition to conducting interviews and collecting historical data, the SRARP has led numerous tours at SRS since the inception of the Community History Project. We have had 15 tours this year, permitting 412 people to visit their former homeplaces, church grounds, and old town sites. Four of these tours were church groups consisting of 73 people, five were family reunion tours consisting of 308 people, and six were individual tours consisting of 31 people. These tours help us to make the public aware of our Community History Project, and perhaps encourage involvement in our work. Also for public outreach, we set up displays at public events, and present papers on the results of our on-going research.

\section{Volunteer Excavation Projects}

The volunteer excavation program at the Tinker Creek site on the SRS continued through FY93 on a monthly basis. Participation by members of the Augusta Archaeological Society was supplemented by contingents of the University of Georgia's Ecology Lab, Westinghouse, Augusta College, USC-Aiken, and the Archaeological Society of South Carolina. Specially scheduled digs were held for Augusta College archaeology students and teachers of SCIAA's Summer Teachers Institute. Over 250 square meters of hand excavation has been accomplished since the Tinker Creek project recommenced in January 1990. Although much more work lies ahead to complete the testing, analyze the artifacts, and to write a report, the work to date has shed much light on long-term use of a Aiken Plateau site by prehistoric households dating from 40002500 years ago. Concurrent cataloging of the Tinker Creek material is made possible by a graduate student assistant to Sarah Jo Evans, Department of Anthropology, University of South Carolina.

In response to the popularity of the open-house excavation of the First Annual Archaeology Week in 1992, SRARP offered two additional opportunities for the public to participate in excavations in 1993. Several volunteers joined the SRARP, the U.S. Forest Service, and the Archaeological Society of South Carolina at the Mims Point excavation in Sumter National Forest. The public was also invited to participate in an excavation at the New Windsor Township site, near Beech Island. In coordination with this excavation, David Crass, Bruce Penner, and Tammy Forehand presented a public lecture on the project. Summaries of these projects are provided in other sections of this report. 


\section{Additional Involvement with Avocational Archaeology Groups}

SRARP staff continue to maintain close ties with the Archaeological Society of South Carolina (ASSC) and the Augusta Archacological Society (AAS). During FY93, Kenneth E. Sassaman continued in his role of journal editor for the society journal, South Carolina Antiquities (ASSC). D. Keith Stephenson continued in an active role with the South Georgia Archaeological Recovery Team (SOGART), a volunteer effort designed to salvage data threatened by land clearing and other terrain alteration. George Lewis was re-elected president of the ASSC, and continued in his role on the Board of Directors of SGA, treasurer of AAS, and editor-publisher of the AAS bi-monthly newsletter, Debitage. Lewis was also instrumental in developing a new chapter of the ASSC in Aiken. 


\section{REFERENCES CITED}

Baker, C. M.

1978 The Size Effect: An Explanation of Variability in Surface Artifact Assemblage Content. American Antiquity 43(2):288-293.

Battarbee, R. W.

1986 Diatom Analysis. In Handbook of Holocene Palaeoecology and Palaeohydrology, edited by B. E. Berglund. International Geological Correlation Programme, Project 158B, John Wiley and Sons, New York.

Brooks, M. J., and K. E. Sassaman

1990 Point Bar Geoarchaeology in the Upper Coastal Plain of the Savannah River Valley, South Carolina: A Case Study. In Archaeological Geology of North America, edited by N. P. Lasca and J. E. Donahue. Centennial Special Volume 4, Geological Society of America, Boulder, Colorado.

Brooks, M. J., K. E. Sassaman, and G. T. Hanson

1990 Environmental Background and Models. In Native American Prehistory of the Middle Savannah River Valley: A Synthesis of Archaeological Investigations on the Savannah River Site, Aiken and Barnwell Counties, South Carolina, by K. E. Sassaman, M. J. Brooks, G. T. Hanson, and D. G. Anderson. Savannah River Archaeological Research Papers 1. Savannah River Archaeological Research Program, South Carolina Institute of Archaeology and Anthropology, University of South Carolina, Columbia.

Brooks, M. J., and B. E. Taylor

1992 Upland Wetlands Investigation of Pleistocene-Holocene Environmental and Anthropogenic Change on the SRS and Vicinity. In Annual Review of Cultural Resource Investigations by the Savannah River Archaeological Research Program: Fiscal Year 1992. Savannah River Archaeological Research Program, South Carolina Institute of Archaeology and Anthropology, University of South Carolina, Columbia.

Ferring, C. R.

1986 Rate of Fluvial Sedimentation: Implications for Archaeological Variability. Geoarchaeology 1:259-274.

Frey, D. G.

1951 Pollen Succession in the Sediments of Singletary Lake, North Carolina. Ecology 32:518-533.

Friedman, G. M., and J. E. Sanders

1978 Principles of Sedimentology. John Wiley, New York.

Gaiser, E. E.

1993 Holocene Diatoms of Carolina Bay Wetlands. Poster session at the Annual Meetings of the American Society of Limnology and Oceanography and the Society of Wetland Scientists, Edmonton, Alberta, Canada.

Hughes, P. J., and R. J. Lampert

1977 Occupational Disturbance and Types of Archaeological Deposit. Journal of Archaeological Science 4:135-140. 
Kaczorowski, R. T.

1977 The Carolina Bays and Their Relationship to Modern Oriented Lakes. Ph.D. Dissertation, Department of Geology, University of South Carolina, University Microfilms, Ann Arbor.

Mahoney, D., M. A. Mort, and B. E. Taylor

1990 Species Richness of Calanoid Copepods, Cladocerans and Other Branchiopods in Carolina Bay Temporary Ponds. American Midland Naturalist 123:244-258.

Pearsall, D. M.

1989 Paleoethnobotany: A Handbook of Procedures. Academic Press, Inc. San Diego.

Sassaman, K. E., M. J. Brooks, G. T. Hanson, and D. G. Anderson

1990 Native American Prehistory of the Middle Savannah River Valley: A Synthesis of Archaeological Investigations on the Savannah River Site, Aiken and Barnwell Counties, South Carolina. Savannah River Archaeological Research Papers 1. Savannah River Archaeological Research Program, South Carolina Institute of Archaeology and Anthropology, University of South Carolina, Columbia.

Sassaman, K. E. and J. C. Gillam

1993 Intensive Archaeological Survey of the F/H Surface Enhancement Project Area, Savannah River Site, Aiken and Barnwell Counties, South Carolina. Technical Report Series Number 18. Report submitted to Savannah River Operations Office, U.S. Department of Energy. Manuscript on file, Savannah River Archaeological Research Program, South Carolina Institute of Archaeology and Anthropology, University of South Carolina.

Savannah River Archaeological Research Program

1989 Archaeological Resource Management Plan of the Savannah River Archaeological Research Program. Report submitted to the Savannah River Operations Office, United States Department of Energy. Manuscript on file, Savannah River Archaeological Research Program, South Carolina Institute of Archaeology and Anthropology, University of South Carolina.

1990 Annual Review of Cul aral Resource Investigations by the Savannah River Archaeological Research Program: Fiscal Year 1990. Savannah River Archaeological Research Program, South Carolina Institute of Archaeology and Anthropology, University of South Carolina, Columbia.

Schalles, J. F., R. R. Sharitz, J. W. Gibbons, G. J. Leversee, and J. N. Knox

1989 Carolina Bays of the Savannah River Plant, Aiken, South Carolina. SRONERP-18, Savannah River Ecology Laboratory, Aiken, South Carolina.

Shields, J. D., N. D. Woody, A. S. Dicks, G. J. Hollod, J. Schalles, and G. J. Leversee 1982 Locations and Areas of Ponds and Carolina Bays at the Savannah River Plant. E. I. du Pont Nemours and Company, Savannah River Laboratory, Aiken, South Carolina.

Stephenson, K. and K. E. Sassaman

1993 Archaeological Survey of the Proposed Central Sanitary Wastewater Treatment Facility, Savannah River Site, Aiken and Barnwell Counties, South Carolina. Technical Report Series Number 19. Report submitted to Savannah River Operations Office, U.S. Department of Energy. Manuscript on file, Savannah River 
Archaeological Research Program, South Carolina Institute of Archaeology and Anthropology, University of South Carolina.

Stephenson, K., D. C. Crass, and K. E. Sassaman 1993 Intensive Archaeological Survey of the Proposed Savannah River Ecology Laboratory Conference Center and Educational Facility, Savannah River Site, Aiken County, South Carolina. Technical Report Series Number 17. Report submitted to Savannah River Operations Office, U.S. Department of Energy. Manuscript on file, Savannah River Archaeological Research Program, South Carolina Institute of Archaeology and Anthropology, University of South Carolina.

Stockton, E. D.

1973 Shaw's Creek Shelter: Human Displacement of Artefacts and its Significance. Mankind 9:112-117.

Taylor, B. E., and M. J. Brooks

1993 Holocene Changes in Wetland Ponds in the Upper Coastal Plain of South Carolina. Paper presented at the Annual Meetings of the American Society of Limnology and Oceanography and the Society of Wetland Scientists, Edmonton, Alberta, Canada.

U.S. Atomic Energy Commission Aerial Photograph

1951 Savannah River aerial photograph 1951-169. U.S. Department of Energy, Savannah River Operations Office, Aiken, SC.

Watts, W. A.

1980 Late-Quaternary Vegetation History at White Pond on the Inner Coastal Plain of South Carolina. Quaternary Research 13:187-199.

Whitehead, D. R.

1981 Late-Pleistocene Vegetational Changes in Northeastern North Carolina. Ecological Monographs 51:451-471. 


\section{APPENDIX A \\ PUBLISHED PAPERS AND MONOGRAPHS}

Anderson, D. G., K. E. Sassaman, and C. Judge (editors)

1992 Paleoindian and Early Archaic Research in the Lower Southeast: A South Carolina Perspective. Council of South Carolina Professional Archaeologists in conjunction with the Savannah River Archaeological Research Program.

Browder, Tanya Algerine, Richard David Brooks, and David Colin Crass

1993 Memories of Home: Dunbarton and Meyers Mill Remembered. Savannah River Heritage Series 1. Savannah River Archaeological Research Program, South Carolina Institute of Archaeology and Anthropology, University of South Carolina.

Crass, David Colin and Richard D. Brooks

1993 Settlement Patterning on an Agriculturally Marginal Landscape. In Historic Landscapes in South Carolina: Historical Archaeological Perspectives of the Land and Its People, edited by L.F. Stine et al., pp. 39-55. Council of South Carolina Professional Archaeologists in conjunction with the Savannah River Archaeological Research Program.

Crass, David Colin and C. Garth Sampson

1993 Glassware and Metalwork Acquired by the Seacow River Bushmen. Martevaan 9: 3-13. Capetown, Republic of South Africa.

Sassaman, K. E.

1991 Adaptive Flexibility in the Morrow Mountain Phase of the Middle Archaic Period. South Carolina Antiquities 23:31-41.

1992 Early Archaic Settlement of the South Carolina Coastal Plain. In Paleoindian and Early Archaic Period Research in the Lower Southeast: A South Carolina Perspective (edited by D.G. Anderson, K.E. Sassaman and C. Judge), pp. 48-67. Council of South Carolina Professional Archaeologists.

1993 Early Pottery in the Southeast: Tradition and Innovation in Cooking Technology. University of Alabama Press, Tuscaloosa.

Stine, L. F., L. M. Drucker, M. Zierden, and C. Judge (editors)

1993 Historic Landscapes in South Carolina: Historical Archaeological Perspectives of the Land and Its People. Council of South Carolina Professional Archaeologists in conjunction with the Savannah River Archaeological Research Program.

\section{TECHNICAL REPORTS}

Crass, David Colin, and George S. Lewis

1993 Excavations at 9RI432 (The Woodrow Wilson Boyhood Home). Augusta Archaeological Society, Augusta, GA.

Sassaman, Kenneth E., with contributions by Mark J. Brooks, David Colin Crass, William Green, George S. Lewis, and Keith Stephenson

1992 Early Woodland Settlement in the Aiken Plateau: Archaeological Investigations at 38AK157, Savannah River Site, Aiken County, South Carolina. 
Draft report submitted to the Savannah River Operations Office, United States Department of Energy.

Sassaman, K. E., with contributions by Mark J. Brooks, Dean C. Foster, Jennifer A. Freer, Daniel A. Kysar, and Ted A. Rathbun.

1993 Archaeological Investigations at Mims Point (38ED9), Sumter National Forest, South Carolina: 1992 (with contributions by M.J. Brooks, D.C. Foster, J.A. Freer, D.A. Kysar, and T.A. Rathbun). Francis Marion and Sumter National Forests Cultural Resource Management Report 93-16.

Sassaman, K. E., and J. C. Gillam

1993 Intensive Archaeological Survey of the F/H Surface Enhancement Project Area, Savannah River Site, Aiken and Barnwell Counties, South Carolina. Savannah River Archaeological Research Program, Technical Report Series 18.

Stephenson, D. K.., D. C. Crass, and K. E. Sassaman 1993 Intensive Archaeological Survey of the Proposed Savannah River Ecology Laboratory Conference Center and Educational Facility, Savannah River Site, Aiken County, South Carolina. Savannah River Archaeological Research Program, Technical Report Series 17.

Stephenson, D. K., M. Williams, R. J. Ledbetter, and T. Pluckhan 1993 Archaeological Investigation at the Wildcat Creek Site (90C169): A Lamar Period Occupation in the Oconee River Floodplain. LAMAR Institute Report.

\section{BOOK REVIEWS}

Sassaman, K. E.

1993 The Siouan Project: Seasons I and II, edited by R.S. Dickens, H.T. Ward and R.P.S. Davis, Jr. American Antiquity 58:374-375.

\section{SYMPOSIA ORGANIZED}

Nassaney, M. S., and K. E. Sassaman

1992 Pre-Columbian Native Encounters. Symposium organized for the Southeastern Archaeological Conference, Little Rock, Arkansas.

\section{PROFESSIONAL PAPERS PRESENTED}

Brooks, M. J.

1992 Alluvial Contexts of Site Formation in the Coastal Plain of the Savannah and South Edisto River Valleys. Invited paper in symposium on Site Formation Processes in the Atlantic Coastal Plain, University of South Carolina, Coastal Carolina, Conway.

Browder, T. A., D. C. Crass, and R. D. Brooks

1993 Oral History at the Savannah River Site. Paper presented at the Annual Meeting of the South Carolina Historical Association, Columbia, SC.

Crass, David Colin

1993 The Development of the Carolina Backcountry: Archaeological Research Domains in the Central Savannah River Valley. Paper presented at the 26th Annual Conference of the Society for Historical Archaeology, Kansas City, MO. 
Goodyear, A. C., S. B. Upchurch and M. J. Brooks

1993 Turtlecrawl Point: Lessons from an Inundated Prehistoric Site in Boca Ciege Bay, Florida. Paper presented at the Annual Meeting of the Florida Anthropological Society, Clearwater Beach, Florida.

Nassaney, M. S. and K. E. Sassaman

1992 Understanding Pre-Columbian Native Encounters. Paper presented in symposium at the 49th Annual Meeting of the Southeastern Archaeological Conference, Little Rock, AR.

Rinehart, Charles J., and Melanie Cabak

1993 Consumer Patterns at Three Early- to Mid-20th Century Farmsteads in Barnwell County, South Carolina. Paper presented at the 26th Annual Conference of the Society for Historical Archaeology, Kansas City, MO.

Sassaman, K. E.

1993 The Social Contradictions of Traditional and Innovative Cooking Technology in the Prehistoric American Southeast. Invited paper presented in symposium at the 58th Annual Meeting of the Society for American Archaeology, Pittsburgh, PA.

1993 Archaeology at Mims Puint. Paper presented at the 19th Annual Conference on South Carolina Archaeology, Columbia, SC.

1992 Colluvial Contexts for Prehistoric Sites in the Aiken Plateau. Invited paper in symposium on Site Formation Processes in the Atlantic Coastal Plain, University of South Carolina, Coastal Carolina, Conway.

1992 Raiders, Traders, and Refugees in the Mid-Holocene of the American Southeast. Paper presented in symposium at the 49th Annual Meeting of the Southeastern Archaeological Conference, Little Rock, AR.

Snow, Frankie, and Keith Stephenson

1993 Swift Creek Designs: A Tool For Monitoring Interaction. Invited paper presented at the Conference on Swift Creek Culture, Macon, GA.

Stephenson, Keith, and Adam King

1992 At the Center of Peripheries: Late Woodland Persistence in the Interior Coastal Plain of Georgia. Paper presented in symposium at the 49th Annual Meeting of the Southeastern Archaeological Conference, Little Rock, AR.

Stephenson, Keith, and Frankie Snow

1993 Hartford Revisited: Surface Reconnaissance at a Swift Creek Village. Paper presented at the 1993 Spring Meeting of the Society for Georgia Archaeology, Red Top Mountain State Park, GA.

Taylor, B. E. and M. J. Brooks

1993 Holocene Changes in Wetland Ponds in the Upper Coastal F ain of South Carolina. Paper presented in the Paleolimnology and Global Environmental Change symposium at the Annual Meetings of the Society of Limnology and Oceanography and the Society of Wetland Scientists, Edmonton, Alberta, Canada. 


\section{JOURNAL CONTRIBUTIONS OF CURRENT RESEARCH}

Brooks, M. J.

1993 Current Research, South Carolina. American Antiquity 58(3):586.

Crass, David C.

1992 Current Research. The Society for Historical Archaeology Newsletter 2j(3):25.

\section{OFFICES/APPOINTMENTS HELD}

Brooks, Richard D.

Chair, Futures Committee, South Carolina Institute of Archaeology and Anthropology.

Crass, David C.

Secretary, Council of South Carolina Professional Archaeologists.

Member, Futures Committee, South Carolina Institute of Archaeology and Anthropology.

Lewis, G. S.

Editor, Debitage (bi-monthly newsletter of the Augusta Archaeological Society).

Board of Directors, Society for Georgia Archaeology.

President, Archaeological Society of South Carolina.

Treasurer, Augusta Chapter of the Society for Georgia Archaeology.

Sassaman, K. E.

Vice-President and Newsletter Editor, Council of South Carolina Professional Archaeologists.

Editor, Archaeological Society of South Carolina (South Carolina Antiquities).

Editor-Elect, Southeastern Archaeological Conference (Southeastern Archaeology)

Member, South Carolina Review Board of the National Register of Historic Places.

\section{TEACHING}

Sassaman, K. E.

Fall Semester 1992 - Adjunct Assistant Professor, Department of Anthropology, University of South Carolina. ANTH 533 - North American Archaeology.

Winter Quarter 1993 - Part-time Instructor, Department of History and Anthropology, Augusta College. ANT 101 - Introduction to Anthropology.

Spring Quarter 1993 - Part-time Instructor, Department of History and Anthropology, Augusta College. ANT 303 - Archaeological Method and Theory. 


\section{PUBLIC SERVICE ACTIVITIES}

October 1992

Browder, T. A.

Guided tour on the SRS for the Hiers-Eaves family.

Crass, David C. and G. S. Lewis

Volunteer excavations at the Woodrow Wilson Boyhood Home (9RI432),

Augusta Archaeological Society, Augusta, GA.

Crass, David C. and G. S. Lewis

Boy Scout Camporee Display, Savannah River Site, Aiken, SC.

Lewis, G. S.

Archaeology and the SRARP. Presentation to Men's Group at Bethel United Methodist Church, Jackson, SC.

Lewis, G. S. and K. E. Sassaman

Volunteer excavations at the Tinker Creek site (38AK224), Augusta Archaeological Society, Augusta, GA.

Sassaman, K. E.

SRARP Archaeology. Presentation to Earth Science Teachers Program, Savannah River Site.

November 1992

Crass, David C.

Commentor, Augusta Canal Authority, Augusta, GA.

Crass, David C. and G. S. Lewis

Volunteer excavations at the Woodrow Wilson Boyhood Home (9RI432),

Augusta Archaeological Society, Augusta, GA.

Lewis, G. S.

Volunteer excavations at the Tinker Creek site (38AK224), Augusta

Archaeological Society, Augusta, GA.

December 1992

Browder, T. A. and D. C. Crass

Guided tour on the SRS for the Ebenezer Church Club.

Crass, David C. and G. S. Lewis

Volunteer excavations at the Woodrow Wilson Boyhood Home (9RI432), Augusta Archaeological Society, Augusta, GA.

Lewis, G. S. and K. E. Sassaman

Volunteer excavations at the Tinker Creek site (38AK224), Augusta

Archaeological Society, Augusta, GA. 
January 1993

Crass, David C.

Urban Archaeology in Augusta, Georgia. Presentation to the Charleston Chapter of the Archaeological Society of South Carolina.

Lewis, G. S. and K. E. Sassaman

Volunteer excavations at the Tinker Creek site (38AK224), Augusta

Archaeological Society, Augusta, GA.

February 1993

Brooks, R. D. and T. A. Browder

Guided tour on the SRS for the Dunbar family.

Crass, David C. and G. S. Lewis

Volunteer excavations at the Woodrow Wilson Boyhood Home (9RI432),

Augusta Archaeological Society, Augusta, GA.

Lewis, G. S. and K. E. Sassaman

Volunteer excavations at the Tinker Creek site (38AK224), Augusta

Archaeological Society, Augusta, GA.

March 1993

Crass, David C.

Consultation with Historic Gardens Specialist, Woodrow Wilson Boyhood Home (9RI432), Augusta Archaeological Society, Augusta, GA.

Commentor, Augusta Canal Authority, Augusta, GA.

Sassaman, K. E.

Mims Point in Regional Context. Presentation to the Charleston Chapter of the Archaeological Society of South Carolina.

Lewis, G. S. and K. E. Sassaman

Volunteer excavations at the Tinker Creek site (38AK224), Augusta

Archaeological Society, Augusta, GA.

April 1993

Inkrot, M. M.

SRARP display for Fishing Rodeo, Get Hooked on Fishing Not on Drugs, sponsored by the South Carolina Department of Wildlife and Marine Resources, Barnwell, SC.

Browder, T. A. and M. M. Inkrot

SRARP display on archaeology and the Community History Project for Earth Day 1993 at the Savannah River Site and Augusta, GA.

Lewis, G. S. and K. E. Sassaman

Volunteer excavations at the Tinker Creek site (38AK224), Augusta

Archaeological Society, Augusta, GA. 
May 1993

Brooks, M. J., B. E. Taylor and E. N. Brooks

SRARP display for Fishing Rodeo, Get Hooked on Fishing Not on Drugs, sponsored by the South Carolina Department of Wildlife and Marine Resources, Graniteville, SC.

Browder, T. A.

Display on the Community History Project at Heritage Day, Beech Island

Historical Society, Beech Island, SC.

Guided tour on the SRS for the Iris Garden Club.

Guided tour on the SRS for the Jackson Senior Citizens.

Browder, T. A. and R. D. Brooks

Guided tour on the SRS for the Dunbarton Reunion.

Lewis, G. S.

Volunteer excavations at the Tinker Creek site (38AK224), Augusta

Archaeological Society, Augusta, GA.

Sassaman, K. E.

Middle Savannah River Valley Prehistory. Two presentations to Westinghouse Engineer Group, Savannah River Site.

Stephenson, D. K.

Career Day presentation at St. Mary's Catholic School, Aiken, SC.

SRARP display at the spring meeting of the Society for Georgia Archaeology, Red Top Mountain, GA.

June 1993

Brooks, M. J., R. D. Brooks, D. C. Crass, M. M. Inkrot, and K E. Sassaman

Presentations to the Summer Teachers Institute, South Carolina Institute of Archaeology and Anthropology.

Browder, T. A.

Guided tour on the SRS for the McLean-Griffen family.

Browder, T. A., D. C. Crass, M. M. Inkrot, and R. D. Brooks

Guided tour on the SRS for the Ellenton Reunion.

Crass, David C.

Historical Archaeology at the Savannah River Site. Presentation to Westinghouse

Engineers, Savannah River Site, Aiken, SC.

Commentor, Augusta Canal Authority, Augusta, GA.

Inkrot, M. M.

Archaeology and the SRARP. Presentation to the Optimist Club, North Augusta, $\mathrm{SC}$. 
Stephenson, D. K.

The Hartford Site and Moundbuilder Feasting. Presentation to the Aiken Chapter of the Archaeological Society of South Carolina.

July 1993

Browder, T. A.

Guided tour on the SRS for the Pike family.

Browder, T. A. and D. C. Crass

Guided tour on the SRS for the Meyer family reunion.

Sassaman. K. E.

Volunteer excavations at the Tinker Creek-site (38AK224), Augusta

Archaeological Society, Augusta, GA.

August 1993

Browder, T. A.

Guided tour on the SRS for the Millans family.

Guided tour on the SRS for the Bush-Weathersbee family.

Guided tour on the SRS for Zion Fair Baptist Church.

Lifeways: Oral History of Ellenton. Presentation to the Bush-Jones-RileyWeathersbee family reunion, Augusta, Georgia.

Lifeways: Oral History of Ellenton and Silverton District. Paper presented at the Jones-Stephens-Bryant family reunion, Aiken, South Carolina.

Browder, T. A. and R. D. Brooks

Guided tour on the SRS for the Bush-Jones-Riley-Weathersbee family reunion.

Browder, T. A. and D. C. Crass

Guided tour on the SRS for the Jones-Stephens-Bi yant family reunion.

Crass, D. C. and M. M. Inkrot

Presentation on archaeology at Charleston County In-Service, Charleston, SC.

Inkrot, M. M.

SRARP display at the Aiken County Schools In-Service.

Sassaman. K. E.

Volunteer excavations at the Tinker Creek site (38AK224), Augusta

Archaeological Society, Augusta, GA.

September 1993

Browder, T. A.

Lifeways: Oral History of the Small Towns and Hamlets on the Savannah River

Site. Presentation to the Wackenhut Quarterly Meeting, on the Savannah River

Site. 
Crass, David C., Bruce Penner, and Tammy Forehand Excavations at 38AK615, the Bartley Site. Presentation to the Beech Island Historical Society, Beech Island, SC.

Discovering Beech Island's Colonial Past. Presentation for South Carolina Archaeology Week, University of South Carolina-Aiken, SC.

Volunteer Excavations at 38AK615, the Bartley Site, Beech Island, SC.

Inkrot, M. M.

Introduction to Archaeology. Presentation to classes at Schofield Middle School, Aiken, SC.

Career Day presentation at Merriwether Middle School, North Augusta, SC.

Interpreting Archaeology for the Public. Presentation at the Historic Sites Interpretation graduate class at the University of South Carolina, Columbia, SC.

Archaeology and the Early Colonial Period. Presentation to classes at South Aiken High School, Aiken, SC.

Introduction to Archaeology. Presentation to classes at Aiken Elementary, Aiken.

Exhibits for Archaeology Week at Nancy Carson Library, North Augusta ; Aiken County Library, Aiken, SC; Displays at Nations Bank, New Ellenton , DOE Headquarters, Savannah River Site, and Fall Field Day, Santee State Park.

Lewis, G. S. and K. E. Sassaman

Volunteer excavations at the Tinker Creek site (38AK224), Augusta

Archaeological Society, Augusta, GA. 

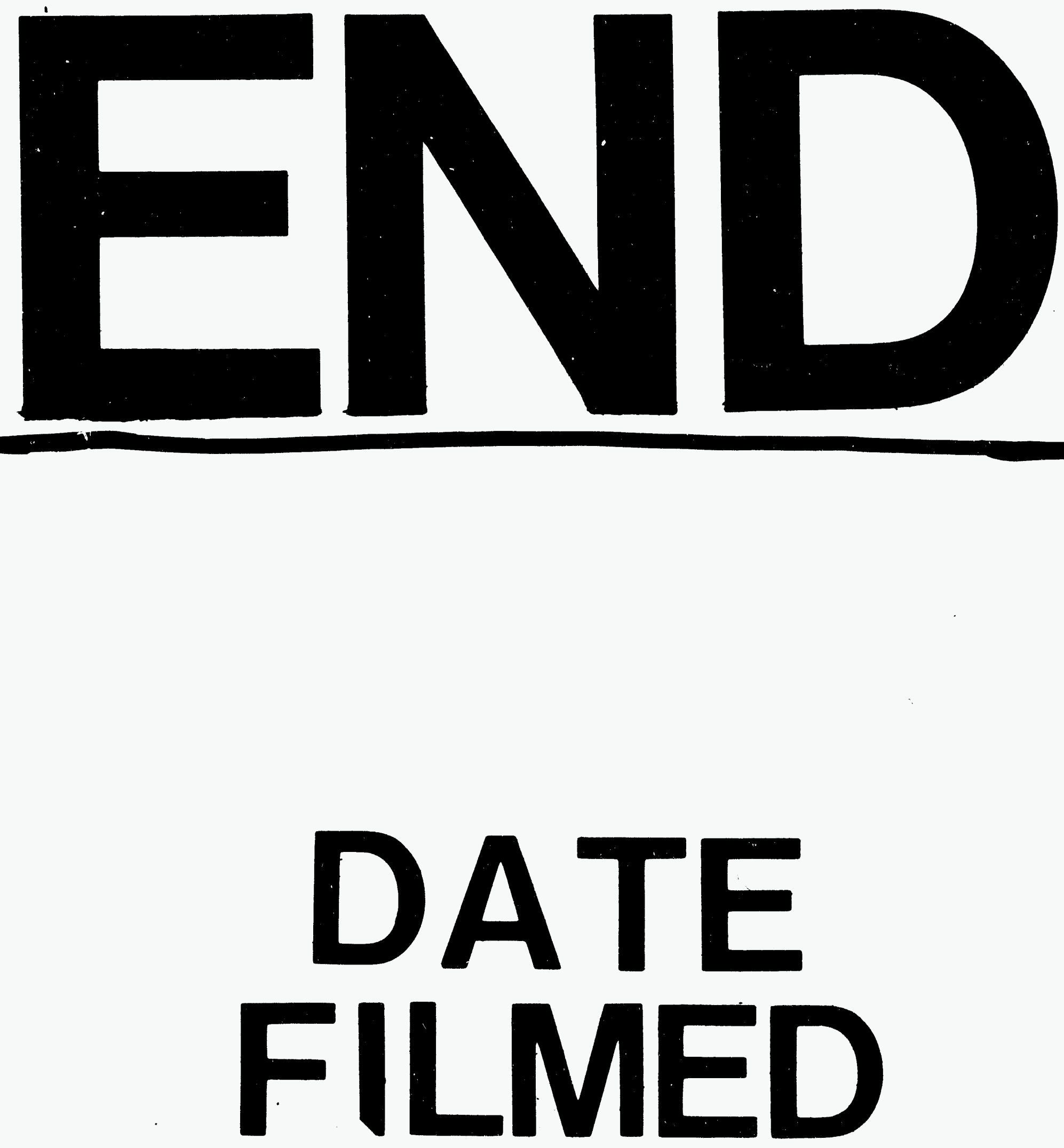

$3 / 28 / 94$ 
